\title{
Gall-Inducing Tephritid Flies (Diptera: Tephritidae): Evolution and Host-Plant Relations
}

\author{
Valery A. Korneyev* for the Ecology and Evolution of Host-Plant Relations of \\ Gall-Inducing Arthropods
}

Department of Entomology and Collection Management, I.I. Schmalhausen Institute of Zoology of the National Academy of Sciences of Ukraine, Kyiv, Ukraine

OPEN ACCESS

Edited by:

Donald Gray Miller III,

California State University, Chico,

United States

Reviewed by:

Dong Zhang,

Beijing Forestry University, China

Allen Norrbom,

Systematic Entomology Laboratory

(USDA-ARS), United States

${ }^{*}$ Correspondence:

Valery A. Korneyev

valery.korneyev@gmail.com

Specialty section

This article was submitted to

Behavioral and Evolutionary Ecology,

a section of the journal

Frontiers in Ecology and Evolution

Received: 30 June 2020

Accepted: 12 May 2021

Published: 12 August 2021

Citation:

Korneyev VA (2021) Gall-Inducing Tephritid Flies (Diptera: Tephritidae): Evolution and Host-Plant Relations.

Front. Ecol. Evol. 9:578323.

doi: 10.3389/fevo.2021.578323
The molecular-based phylogenetic analysis of the subfamily Tephritinae, the subfamily that contains almost all the cecidogenous species of the family Tephritidae, has reassigned several tribes and groups of genera and modified their concepts based on morphology alone to other tribes and, thus, changed the hypothetical scenarios of evolution of fly/host-plant relations and, in particular, the gall induction in different phylogenetic lineages. Gall induction is shown to arise independently within the Myopitini (in two lineages), Cecidocharini, Tomoplagia group of genera, Eurostini, Eutreta, Tephritis group of genera, Platensinini, Campiglossa group of genera, and Sphenella group of genera independently and more or less synchronously due to the shift to host plants with smaller flower heads and sensitive to larval feeding causing tissue proliferation. This was possibly a result of temporary aridization of the grassy biomes in the Nearctic and Afrotropic regions in the late Miocene or early Pliocene.

Keywords: Diptera, Tephritidae, gall-inducers, evolution, Asteraceae

\section{INTRODUCTION}

The so-called "true fruit flies" (Tephritidae) actually include almost 5,000 species with a wide range of larval feeding preferences: from saprophages under the bark of dead trees or within bamboo culms (Phytalmiinae, Gastrozonini), insect parasitoids (Tachiniscinae) through stem borers in variable herbaceous plants (Blepharoneurinae, Adramini, Trypetina, Zaceratini, and Tephritinae Terelliini), to real fruit feeders (Blepharoneurinae, Ceratitidini, Dacini, Adramini, Carpomyini, Toxotrypanini, and some Trypetinae), borers and seed eaters in the flower heads of Asteraceae (most Tephritinae), flower and seed feeders of Lamiaceae and Acanthaceae (Tephrellini and Pliomelaenini), and finally, gall inducers predominantly in Asteraceae flower heads, stems, and rhizomes (Tephritinae). The only gall-inducing tephritids beyond the subfamily Tephritinae are the species of the genus Notomma Bezzi (Carpomyini Notommatina), whose larvae are able to induce galls in twigs of Dicrostachys and Vachellia (Fabaceae) (Munro, 1952).

The total number of gall-inducing tephritid species is estimated to be about $400-450$, i.e., $6-7 \%$ of the known Tephritidae species. After the Cecidomyiidae, tephritid gall inducers are, therefore, the second most numerous among the dipteran families (Freidberg, 1984, 1998).

The previous surveys by Freidberg $(1984,1998)$ and Korneyev et al. (2005) are important sources summarizing the data on gall-inducing tephritids. Except for some more recent records of gall induction by tephritids, for example, by Prado et al. (2002), Norrbom et al. (2010), Warton and Norrbom (2013), Norrbom et al. (2013), or Savaris et al. (2019), readers should refer to the above summary for further sources of primary data. They (and foremost Freidberg, 1984, 1998) reviewed 
studies on the biology of gall-inducing tephritids and the recent information. In the current paper, I review the improvements and most of the available data since 2004, analyze the distribution of cecidogeny throughout the family, and provide new perspective on the evolution of gall-forming tephritids in light of changes to the phylogeny and classification of the subfamily Tephritinae (Korneyev et al., 2005) proposed by Han et al. (2006).

\section{Discordance Between Overall Similarity and Phylogeny}

To understand evolution of cecidogeny in the Tephritinae, one must have a sound phylogenetic taxonomy of the subfamily. The hypothesis of Korneyev et al. (2005) was based exclusively on the morphology-based phylogenetic analysis by Korneyev (1999b), but a few years later, Han et al. (2006) published a phylogeny based on mitochondrial 16S ribosomal RNA gene sequences using 53 species representing 11 currently recognized tribes of the Tephritinae. This study concurred that some lineages proposed by Korneyev (1999b) are monophyletic, but did not support the monophyly of others. The main differences were that the tribes Dithrycini, Tephritini, and Eutretini sensu Korneyev (1999b) were either polyphyletic or paraphyletic in spite of the strong similarity of several morphological characters previously believed to be synapomorphies.

\section{Paleontological Data}

Gentilini et al. (2006) gave an overview of the known fossil record of the superfamily Tephritoidea, which clearly shows that at least one identifiable species of Tephritis closely related to recent species already existed in the Late Miocene of Europe (7 mya). This is the only calibration constraint for estimation of divergence time for the Tephritinae. Han and Ro (2016) estimated that the first Tephritidae evolved around the late Eocene ( $\sim 36$ mya), which appears to be a reasonable hypothesis.

\section{Biogeography}

Most Tephritinae tribes and groups of species occur in, or are restricted to, only one or two neighboring zoogeographic regions, such as the Palaearctic and Afrotropical, Afrotropical and Oriental, Palaearctic and Nearctic, or Nearctic and Neotropical regions.

All the Tephritinae, including most gall-inducing species, are associated with herbaceous plants except for a few phylogenetically recent forms secondarily feeding on asteraceous goodeniaceous shrubs and trees. They evolved together and simultaneously with grassy biomes. Zherikhin (1994) assumed that grassy biomes formed since herbivorous ungulates appeared in North America in the Oligocene (Webb, 1977) and became widely distributed afterward together with typical plants of prairies especially in the Miocene, when several waves of invaders entered Asia via the Bering Land Bridge and then Europe and Africa (Zoogeography of Asian Paleogene, 1984).

However, some biogeographic distributions could be better explained by the North Atlantic Land Bridge (NALB) hypothesis. The NALB was usually assumed to have functioned as a corridor for plant (and animal) migration only during the first half of the Cenozoic (Marinkovich et al., 1990; Tiffney and Manchester, 2001); after this time, dispersal mechanisms and climate conditions would have become limiting factors to migration across the Atlantic. Furthermore, it has been assumed that lineages with Eurasian-American divergence times $<30$ mya, i.e., younger than Eocene, could not have passed through a North Atlantic Land Bridge but, instead, would more likely have moved through the Bering link (Donoghue and Smith, 2004). Nevertheless, patterns of distribution of the tephritid taxa with presumably North Atlantic and Bering paths of distribution would be clearly different, and many older taxa of the Tephritinae formed, more probably, with the impact of the North Atlantic Land Bridge.

Recently, Denk et al. (2010) listed a number of indirect paleobotanic proofs of activity of the NALB long after the Eocene, 8-10, 4.9 mya, or even younger, indicating possible gene flow across the North Atlantic via Iceland in the Late Miocene.

\section{Gall-Inducing Tephritinae: Tribes and Genera Phylogenetic Relationships}

The subfamily Tephritinae includes about $99 \%$ of all cecidogenous tephritid species. The concept of this subfamily was established due to the studies of Hancock (1986, 1990, 2001, 2003, 2006, 2007, 2010, 2012), Norrbom (Foote et al., 1993; Norrbom et al., 1999), and (Korneyev, 1988, 1999a; Korneyev et al., 2005) to include mainly the taxa associated with Asteraceae flower heads, and other closely related tephritids that feed on nonasteraceous plants. Recently, Hancock et al. (2021) proposed to include the tribe Zaceratini (incertae sedis; withthree to four species associated with Asparagus, non-gall-inducing), which is the sister group of Tephritinae (Korneyev, 1999b; Han et al., 2006) within the Tephritinae as a basal taxon. This taxonomic decision needs additional studies, and I leave that tribe beyond the scope of the present paper.

Here, I follow the "morphology-based" phylogenetic classification (Korneyev, 1999b) corrected according to the results of molecular-based phylogenetic analysis (Han et al., 2006), with some additions and corrections based on new improvements proposed by Hancock (loc. cit. and Hancock et al., 2021). To understand the origin of cecidogeny in the Tephritinae, I consider mainly the tribes that include gall-inducing flies. For the taxa excluded from this overview (see Korneyev et al., 2005).

\section{Phylogeny, Zoogeography, Classification, and Evolution of Gall Induction}

For the purposes of this paper, the phylogenetic relationships among the taxa of Tephritinae including gall-forming genera or species, are hypothesized as follows (Figure 1):

Lineage 1 generally corresponds to the "Lower Tephritinae" sensu Korneyev (1999b) minus Terelliini, whereas Lineage 2 contains the "Higher Tephritinae" sensu Korneyev (1999b) plus Terelliini.

Lineage 1 has a basal bifurcation into a monophyletic Lineage 3 , which corresponds to the tribe Schistopterini together with the genus Ensina Robineau-Desvoidy 1830, and Lineage 4, which includes the remaining taxa. 


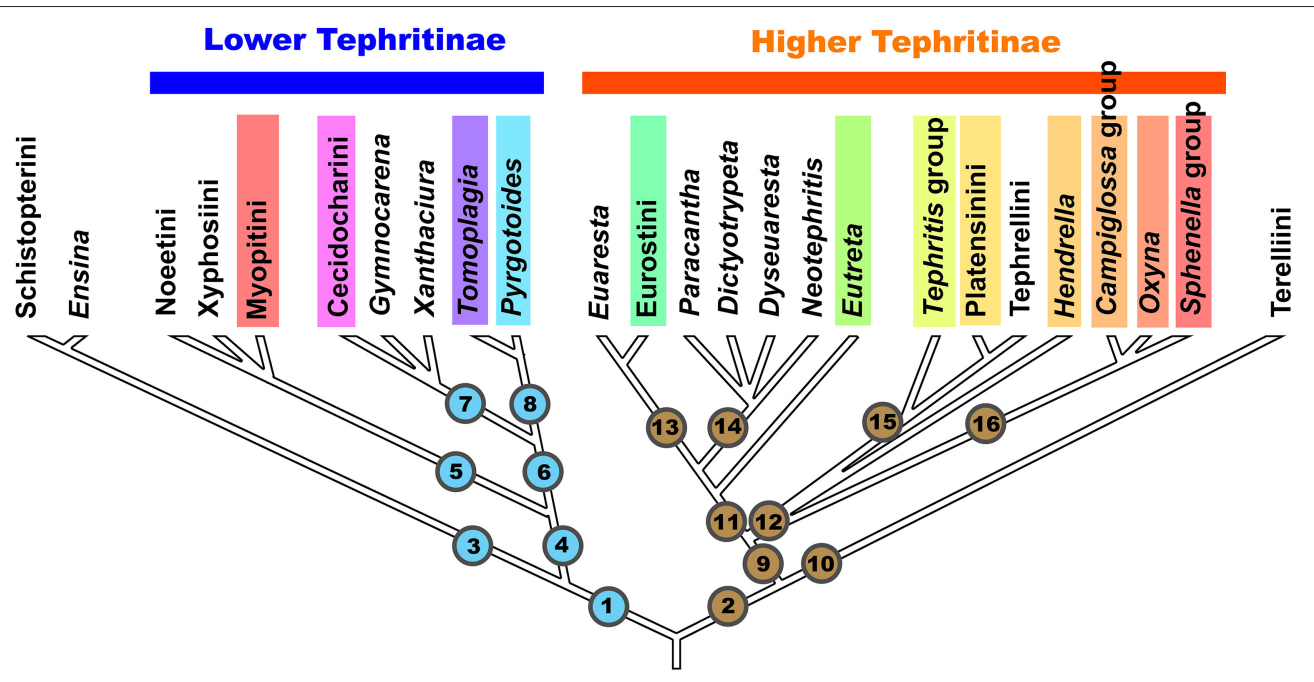

FIGURE 1 | Scheme of phylogenetic relationships among the tribes, groups of genera, and genera of the subfamily Tephritinae (based on Han et al., 2006). Color bars mark the taxa, which include gall-inducing species.

\section{HOLARCTIC AND SUBCOSMOPOLITAN "LOWER TEPHRITINAE"}

\section{Schistopterini}

In both $16 \mathrm{~S}$ and COI-based phylogenies (Han et al., 2006; Smit et al., 2013), Ensina and the tribe Schistopterini (16S) have been recovered as a basalmost monophyletic cluster within Lineage 1. Korneyev (1999b) assigned Ensina to the tribe Noeetini based on a single shared morphological character, the barbed apex of the aculeus, as well as sharing host plants of the same tribe. Later, Freidberg (2002) and Freidberg et al. (2020) described similar aculeus shape for the schistopterine genera Microtreta Freidberg and Tanzanimyia Freidberg and Zonstein. As far as known, the morphological diversity of the Schistopterini does not contradict the inclusion of Ensina; thus, I here transfer Ensina from the Noeetini to the Schistopterini as a basal lineage. Larvae of Ensina live in flower heads of various Cichorieae plants, which are more common in the Old World; three or more species occur in the Andes, one species has a subcosmopolitan distribution, and two are endemics of Madeira and Azores. Larvae of the other Schistopterini live in flower heads of Plucheae, Vernoniaeae, Inuleae, and possibly Heliantheae (Hardy, 1973; Freidberg, 2002). The schistopterine genera other than Ensina occur in the paleotropics (with the center of diversity in the Afrotropical region) extending into the Palaearctic region. Such a distribution better corresponds with an early transatlantic rather than a Beringian invasion into the New World. This group (Lineage 3) includes no known gall inducers.

Lineage 4 includes all other "Lower Tephritinae." Within this group, the monophyletic Lineage 5 is represented by three tribes-Noeetini, Xyphosiini, and Myopitini-that have predominantly Holarctic distributions, with some taxa extending mostly into the mountainous areas of the Neotropical, Oriental, and Afrotropical Regions. Lineage 6 is represented by the purely
New World genera Gymnocarena, Xanthaciura, Tomoplagia, Pyrgotoides, and tribe Cecidocharini.

\section{Noeetini}

This tribe includes at least 12 species belonging to five genera, two in the New World, Acidogona Loew (=Xenochaeta Snow) and Jamesomyia Quisenberry, and three in the Old World: Hypenidium Loew, Noeeta Robineau-Desvoidy, and Paracanthella Hendel. Larvae feed in Lactuca and Hieracium (Cichorieae), always forming a chamber with a single larva within a slightly swollen flower head.

It is assumed that the prevention of opening of the flower head may be caused by the larval saline influence in the receptacle tissues, though no obvious galls are formed. Similar to some Schistopterini (including Ensina), all the noeetines have a barbed aculeus with the cerci not entirely integrated into it but still partly separated, which, therefore, cannot be considered a synapomorphy as was assumed by Korneyev (1999b).

The species of Acidogona, Xenochaeta, and Noeeta can live in as far northward as $65^{\circ} \mathrm{N}$ and in association with coniferous and mixed forests, with the diversity of species higher in North America and in Europe, and a few species occurring beyond this area, as far as Far East Palaearctics and highland Guatemala (Korneyev and Ovchinnikova, 2004; Norrbom et al., 2010), which possibly resulted from an originally circumatlantic distribution of the ancestral forms.

\section{Xyphosiini}

The tribe includes eight Palaearctic species in three genera (Ictericodes Hering, with three species associated with Inulae plants, the monotypic Valera Mohamadzade whose host plants are unknown, and Xyphosia Robineau-Desvoidy, with four species associated with Cardueae plants (Merz, 1994; Korneyev and Ovchinnikova, 2004), and also the Nearctic genus Icterica Loew with two species associated with Bidens (Coreopsideae) 
in northeastern North America, and the most diverse genus of the tribe, Neaspilota Osten Sacken with three subgenera: Neaspilota s. str. with four species associated with Vernonieae, Neorellia Freidberg and Mathis with 15 species associated mainly with Astereae, Heliantheae, and Plucheae, and the monotypic Footerellia Norrbom and B. Foote feeding in Coreopsis (Heliantheae).

Similar to noeetines, the distributional pattern of the tribe Xyphosiini possibly shows only the impact of the circumatlantic distribution of the ancestral forms in the Miocene, with more recent invasions from Europe into the Eastern Palaearctic, where the diversity is lowest.

Larvae of Xyphosiini do not show an ability to induce growth of plant tissues; however, receptacle tissues of Inula infested by larvae of Ictericodes japonicus (Wiedemann 1817) become conspicuously harder but neither swollen, nor preventing flower head opening.

\section{Myopitini}

This tribe includes 11 genera of predominantly Holarctic distribution and $>130$ described and at least 30 undescribed species recognized in collections. The relationships among the genera have been analyzed by Freidberg and Norrbom (1999) and Korneyev et al. (2005).

The majority of species in the basal lineages such as Eurasimona Korneyev and White, Goedenia Freidberg and Norrbom, Myopitora Korneyev and White, Rhynencina Johnson, and Inuromaesa Korneyev and White of known biology do not form galls. After ovipositing between phyllaries of preblossoming flower heads, the first instar larvae penetrate into ovules and feed there and in soft achenes forming dry chambers [as described by Goeden et al. (1995b) for Goedenia timberlakei (Blanc and Foote 1961) (as Urophora timberlakei), see Korneyev et al. (2005) for references]. Similarly, larvae of Urophora quadrifasciata (Meigen 1826) feed in fertilized ovarioles, stimulating fascicular parenchyma and the young undifferentiated tissues to proliferate (Varley, 1937; Arnold-Rinehart, 1989; Harris and Shorthouse, 1996; Burkhardt and Zwölfer, 2002), which can be considered as a primitive form of gall induction within Urophora and possibly the Myopitini as a whole.

Apparently, the only evidence of connection between New and Old World genera via the Bering Land Bridge is the presence in Far East Asia of Myopitora shatalkini (Koneyev and White 1991), which is apparently the sister group of Goedenia Freidberg and Norrbom from Western North America. Species of both genera have host plants of the same tribe Astereae, and Myopitora is believed to be the result of a quite recent, possibly Pleistocene, disjunction.

Two other New World genera of the Myopitini, Rhynencina Johnson and Neomyopites Freidberg and Norrbom, with more than 35 species in the Nearctic and Neotropical Regions (including Mesoamerica and South America as far southward as Bolivian Andes and southern Brazil) associated predominantly with Heliantheae plants (and a few Astereae, Eupatorieae, and Liabeae) (Freidberg and Norrbom, 1999), are believed to have evolved after the conjunction of North and South America with the Central American land bridge in the Pliocene. Most of them do not induce galls, but some Neomyopites larvae, which induce stem or achene galls (Freidberg and Norrbom, 1999).

The origin of the Old World Myopitini is disputable. The genus Eurasimona Korneyev and White, which has a bulky phallic glans somewhat similar to species of the Nearctic Goedenia, is believed to be the sister-group of the other Old World genera. Eurasimona species are associated with Anthemideae plants and are restricted in their distribution to western Eurasia. I, therefore, assume that the disjunction of the New and Old World myopitines took place in the Miocene after the North Atlantic Land Bridge ceased to exist.

Morphology-based phylogenies (Freidberg and Norrbom, 1999; Korneyev et al., 2005) do not recover the Old World Myopitini as a monophyletic group, with at least Rhynencina nested within it, but this placement has not been tested by molecular phylogenies as they have not included Rhynencina.

Apart from Asimoneura Czerny, Inuromaesa Korneyev and White, Spinicosta Freidberg and Norrbom, and the basal dzieduszyckii, nigricornis, and quadrifasciata species groups of Urophora (Korneyev and White, 1992), two lineages, Stamnophora + Myopites, and most Urophora, induce welldeveloped galls (Korneyev et al., 2005).

Phylogenetic relationships among the species of Stamnophora and Myopites remain obscure, as well as their nomenclature and systematics. Most data and references have been summarized by Korneyev et al. (2005). Since then, neither revisions, nor comprehensive keys have been published; several undescribed species recognized in collections are still undescribed. This lineage is believed to be monophyletic (Freidberg and Norrbom, 1999; Korneyev et al., 2005), but Stamnophora, which is widespread in the Afrotropical Region, may be paraphyletic, with Myopites nested within it. A few additions to these data have become available: Asimoneura shirakii Munro 1935 from Taiwan was transferred to Myopites due to having mouth parts typical for the latter genus (Korneyev, 2016), but neither comprehensive keys, nor revisions with the description of species mentioned by Freidberg and Norrbom (1999) have been published since then, and the nomenclature and phylogenetic relationships of many taxa remain vague.

Should the cases of obviously athropogenic invasions be excluded, the distribution of species of these two genera is restricted to the Afrotropics (the center of diversity of Stamnophora) and the Mediterranean region (the center of diversity of Myopites), with a few species distributed in temperate Europe and the Middle East.

Myopites shirakii from Taiwan and M. flavovaria (Becker 1913) from Baluchistan are the basalmost species of Myopites, which share several symplesiomorphies with Stemonocera (shape of cell $\mathrm{r}_{4+5}$, bulky head) (Korneyev, in preparation). This distribution apparently reflects an early invasion from Africa, as Arabia connects Asia.

The European and Middle Eastern Myopites, which form a monophyletic group separated from both the African and South Asian species, appear to form a quite young circumMediterranean complex of moderately or poorly differentiated forms associated with different species of Inula (s. 1.) and 
Pulicaria (tribe Inuleae), perhaps formed from several allopatric species in the Pliocene or later.

The Canarian species Myopites nigrescens Becker, 1908 differs from all the other Palearctic species both by morphological features as well as by gall location: it induces stem galls on Schizogyne of the tribe Inuleae (Merz, 1992) and may represent a different phylogenetic lineage.

The Afrotropical Myopites are more diverse morphologically and have a wider range of host plants: M. hemixantha (Munro 1931) feeds in flower heads of Geigeria (Inuleae), M. delottoi (Munro 1955) in Spheranthus of the tribe Plucheae (sometimes included in Inuleae), whereas several undescribed species feed in Phagnalon of the Gnaphalieae and Echinops of the Cardueae, which means that there possibly was a shift to the Inuleae that coincided with the invasion of their ancestors into Eurasia. The host plants of the South Asian Myopites shirakii and M. flavovaria are unknown.

Afrotropical Stamnophora species are known to feed on the Vernonieae, forming simple multilocular galls with a common exit channel without achenes (S. vernoniicola Bezzi on several Vernonia), which is believed to be a generalized type of gall; undescribed species of Stamnophora (see Freidberg, 1998), and flower-head and stem galls of Myopites species with known host plants (Freidberg, 1980, 1984), are derived from them.

Myopites inulae Roser, 1840 gall formation and structure has been described by Arnold-Rinehart (1989) (as "M. blotii"). In egg-laying experiments, she observed that a broad spectrum of flower heads were accepted for oviposition: even in open flower heads, the outer tubular flowers of which already protruded above the bracts, oviposition could be observed into or between the single flowers that had not yet blossomed in the middle of the flower head. The adults feed from the tubular flowers with extremely long and narrow labella different from those in Urophora (and Stamnophora-VK). Obviously, Myopites depend on food intake as adults, in contrast to Urophora species, which can produce eggs without carbohydrate or protein food intake (Varley, 1947).

Arnold-Rinehart (1989) has shown by histological sections that M. inulae (as "M. blotii") eggs are laid between or in tubular flowers. The larvae hatch after about 5 days, then mine in a tubular flower through the achenes and stimulate the fascicular parenchyma to proliferate; the larvae also stimulate the cells in the achenes to divide, thereby enlarging the ovules. The resulting nutrient cells are almost always restricted to the area around the achene structures. The gall genesis of $M$. inulae is an ongoing process in which no individual development phases could be identified. The many clumped cell wall residues bordering the larval cavity in many places are very striking. In order to get to the underlying tissue, the larva obviously presses these cell wall remains aside, grasping the cell wall of the nutrient cells, and only absorbing the contents. The empty cells collapse, and their walls are pushed aside, similar to cynipids, which likewise only consume the cell contents and not the cell walls. As the cell wall remains occur here to a greater extent than in the Urophora galls, it can be assumed that the larvae of $M$. inulae absorb significantly more cell material than those of Urophora. According to ArnoldRinehart (loc. cit.), after about 6-8 weeks, a flower head becomes significally swollen, with larval cavities much larger compared with those infested by Urophora, irregularly reaching the flower head base. Freidberg (1980) and Arnold-Rinehart (loc. cit.) estimated the Myopites larval cavity size to be four or more times as long as the length of the larva, whereas Urophora gall cavities are only twice the length of the larva. The larval cavities of both Stemonocera and Myopites are not perpendicular to the receptacle, but rather irregularly directed.

The exit chimneys of Myopites galls contain no callus tissue (contrary to Urophora galls). They are bordered by a thin pressed layer of cell wall remains as described above, which obviously prevents the exit chimneys from collapsing or growing together (Freidberg, 1980, 1984; Arnold-Rinehart, 1989). After 6-8 weeks sclerenchymation begins in the upper area of each chamber similar to Urophora. Additionally, in the lower part of the flower head, the cell walls in the intercellular tissue begin to sclerenchymize, as was never observed in Urophora.

Arnold-Rinehart (1989) observed much higher mobility of the Myopites larva in freshly dissected galls. The consistency of such a freshly dissected flower head with a Myopites gall in the last stage is cork-like, which is due to the lignification of the intercellular tissue in the lower part of the receptacle. The gall genesis is complete only after 8 weeks. The sclerenchyma protective layer of the individual gall chambers of a gall are fused into a block.

The larvae of Urophora induce lignified galls only in the achenes and receptacles of Cardueae plants (tribes Carduineae and Centaurineae).

Zwölfer and Arnold-Rinehart (1993) overviewed the types of larval feeding in Urophora: (1) non-lignified achene galls ( $U$. quadrifasciata, apparently also species of the dzieduszyckii and nigripalpis groups); (2) lignified cup-shaped unilocular ovaryreceptacle galls ( $U$. affinis, $U$. pauperata, $U$. sirunaseva, and $U$. jaculata); (3) lignified cup-shaped multilocular ovary-receptacle galls (U. cuspidata, U. jaceana, U. hispanica, U. kasachstanica, and $U$. variabilis); (4) lignified block-shaped multilocular ovaryreceptacle galls $(U$. congrua, $U$. coronata, $U$. mauritanica, $U$. solstitialis, U. stylata, U. stalker, and U. terebrans); and (5) multilocular galls on shoots [U. cardui and U. misakiana (Han and Kwon, 2000)].

The Cardueae are usually attacked by a wide range of phytophagous insects, including weevils, moths, cynipid wasps, and other tephritid flies (Zwölfer and Romstöck-Völkl, 1991). The lignified galls better protect Urophora from the other members of these phytophagous guilds as well as from the parasitoids, and they are believed to be an effective adaptation for breeding in plants with numerous competitors. However, the non-lignified gall inducers and the non-gall-inducing species sometimes have certain benefits in comparison with other Urophora species from a faster rate of larval development and from the broader temporal window for oviposition, especially those having two or three generations per year (as $U$. quadrifasciata), which give them higher potential annual reproduction than the univoltine $U$. jaceana and possibly similar species, which induce lignified unilocular or multilocular galls (Burkhardt and Zwölfer, 2002). Urophora jaceana, and apparently some other species, oviposit into an earlier bud stage with the second instar larva hatching from the egg and 
immediately starting to induce the gall, preventing competitors from occupying the flower head.

The lignified block-shaped multilocular ovary-receptacle galls usually occupy most of the flower head, have a robust protective part with more layers of sclerechyma cells and a stronger incorporation of receptacle tissue into the lignified part of the gall (Arnold-Rinehart, 1989; Zwölfer and Arnold-Rinehart, 1993).

The lignified multilocular galls on shoots of Cirsium induced by the European U. cardui and its Far East vicariate U. misakiana evolved from the lignified block-shaped multilocular ovaryreceptacle galls; at least the first species is able to form them in flower heads under in vitro and in vivo conditions (Lalonde and Shorthouse, 1985). Unlike the species inducing flower head galls, those in the shoot galls have no competitors. Larger galls provide better protection from Eurytoma wasps (Zwölfer and ArnoldRinehart, 1993). The high specialization for inducing galls in the stems and shoots restricts the distribution of these flies to wet meadows: unless exposed to water in the spring, the dry galls prevent exit of adult flies from the gall through the narrow and hard "chimneys."

Smit et al. (2013) included over 100 COI sequences of 16 morphologically identified species of Urophora, resulting in multiple placements of several species and a mean distance of a mere $1.65 \%(0.3-2.45 \%)$. Such low genetic distances between them may be a result of very recent diversification, possibly during the upper Pleistocene. This group evolved fast by adaptation strictly to certain host plant species (or species groups). Gall-forming species oviposit early, during a very short time span, being dependent on strict synchronization with their host plants (Zwölfer, 1985). Gall-inducing Urophora species coexisting on the same host plant evolved differences in the selection of oviposition sites or the timing of larval development (Zwölfer, 1985).

This gall-inducing strategy was evolutionarily successful as Urophora soon became widespread throughout the Palaearctic Region from Morocco to Japan and from Sweden and Kamchatka to the Near East and Taiwan. They are restricted to the grassy biome with Cardueae plants, from wet meadows to steppes, Mediterranean phrygana and subdeserts, and are apparently dependent on the grazing of big ungulates, as their host plants usually colonize areas overgrazed or otherwise denuded of climax vegetation.

Palaearctic Myopites species are usually restricted to warmer areas of the Mediterranean region and Middle East, where they occur in wet or mesophilous grasslands near rivers, brooks, marshes, or sea shores preferred by Inula and Pulicaria plants.

Thus, gall-induction independently evolved in three rather distant lineages of the tribe Myopitini, Stamnophora + Myopites, part of Urophora and part of Neomyopites under different conditions, in different geographic regions, and in morphologically different plants. Larvae of other genera of the tribe are believed to produce cytokinine-like hormones with saline to stimulate moderate proliferation of plant cells as the manifestated gall inducers do.

\section{Axiothaumini}

This tribe with at least 20-25 species in three genera of strictly Afrotropical or paleotropical distribution, originally recognized by Korneyev (1999b) as a group of species within the Lower Tephritinae and later formally raised to tribal rank (Hancock, 2003), has not been included in any molecular phylogenies and is not shown on the figure, so its relationships remain obscure. This group may be somehow related to the Myopitini or could be a basal group. Most of the known host-plant species belong to the Senecioneae, but no galls have ever been reported (see Freidberg and Hancock, 1989).

\section{THE NEW WORLD “LOWER TEPHRITINAE”}

Korneyev (1999b) discussed the possible relationships of the Tomoplagia group of genera (Acrotaeniini in part), Cecidocharini, and Gymnocarena, based on general similarity of male and female genitalia that look to be symplesiomorphic with Xyphosiini and Terelliini, but did not identify any sound synapomorphies for them. The $16 \mathrm{~S}$ molecular phylogeny (Han et al., 2006) surprisingly recovered these purely New World "Lower Tephritinae" as a monophyletic Lineage 6 (Figure 1). DNA sequences remain unavailable for many genera of the Tomoplagia group (Acrotaeniini, pro parte major) and Cecidocharini, and here I discuss their position based on the general similarity of additional morphological characters alone. Relationships of some Nearctic genera such as Stenopa still need confirmation by molecular-based analysis. In turn, Lineage 7 corresponds to the tribe Cecidocharini, with the genera Gymnocarena and Xanthaciura as basal lineages, whereas Lineage 8 corresponds to the genus Tomoplagia of the tribe "Acrotaeniini" (validity of the tribal name needs clarification, as the type species of Acrotaenia may belong elsewhere) plus the genus Pyrgotoides Curran (=Gerrhoceras Hering) previously assigned to the "Higher Tephritinae" (Korneyev, 1999b; Korneyev et al., 2005).

\section{Gymnocarena Hering}

This genus includes 19 species occurring in the Nearctic Region and highland areas of the Neotropical Region (Norrbom, 1992, 2006; Sutton et al., 2012), and breeding in flower heads of Helianthus, Heliomeris, Verbesina (Heliantheae), and Dahlia (Coreopsideae) inducing no galls. It is believed to be the most generalized group in Lineage 6, being similar to Xyphosiini and even recovered in the same lineage with them in one analysis (Korneyev, 1999b).

\section{Xanthaciura Hendel}

The 17 species of this genus occur predominantly in Mesoamerica and South America from Mexico and Bahamas to Argentina, with two species extending their distribution into the central and northern United States (Norrbom et al., 1999). All the species of known biology feed mostly in flower heads of Eupatorieae (Ageratum, Eupatorium, and Chromalaena) and Coreopsideae (Bidens and Dahlia) as well as some other tribes inducing no galls (Aczél, 1950, 1952; Foote et al., 1993). The genus was placed into "Tephrititini incertae sedis" (Norrbom et al., 1999), but Han et al. (2006) recovered it in a well-supported lineage with Gymnocarena and Cecidocharini. 


\section{Cecidocharini}

Norrbom et al. (1999) defined this group as a subtribe of Dithrycini to include 10 genera. Korneyev (1999b) refined the tribe to include Cecidochares, Neorhagoletis Hendel and Procecidochares Hendel (=Callachna), and Procecidocharoides Foote, and transferred them into the "Lower Tephritinae" leaving Dracontomyia Becker (=Cecidocharella Hendel), Ostracocoelia Giglio-Tos, and Stenopa Loew as "incertae sedis" (either related to Cecidocharini or to Eutretini), assuming the latter genera to have some synapomorphies with the "Higher Tephritinae" (shorter lateral vertical setae and the row of setulae on vein $R_{1}$ with a gap), both characters quite probably appeared due to homoplasy. Han et al. (2006) recovered Cecidochares and Procecidochares in a well-supported monophyletic lineage.

The nominal genera Gerrhoceras and Pyrgotoides, formerly assigned to Cecidocharini by Norrbom et al. (1999) and retained in the Dithrycini by Korneyev (1999b) and Korneyev et al. (2005), are discussed below. Most cecidocharine species, whose hosts are known, induce galls on plants of the tribes Eupatorieae, Astereae, and Heliantheae (Freidberg, 1984, Foote et al., 1993).

The North American Procecidocharoides penelope (Osten Sacken) larvae infest flower heads of Eupatorium (Eupatorieae) without inducing galls and leave the flower head to pupariate in the soil (Stoltzfus, 1974). Larval host plants of the monotypic Neorhagoletis from the central Andes remain unknown.

Most of the 11 described species (Norrbom et al., 1999, 2010) of Cecidochares occur in South America, with only one of them, C. caliginosa (Foote 1960), extending through Mexico to the southern United States. The species of Cecidochares of known biology are all associated with Eupatorieae, and most are gall inducers (for references, see Prado et al., 2002). Three additional species of Cecidochares were reared from flower heads of Eupatorieae plants, although one species of the C. connexa complex induces a gall in the flower heads of Chromolaena laevigata (Prado et al., 2002).

Eighteen species of Procecidochares are restricted to North America, ranging from Canada to Guatemala (Norrbom et al., 1999, 2010; Goeden and Norrbom, 2001); the position of a single species from Paraguay, P. pleuritica Hendel 1914, needs verification. Their larvae breed in Archibaccharis, Chrysothamnus, Conyza, Corethrogyne, Ericameria, Erigeron, Grindelia, Heterotheca, Solidago (Astereae), Ageratina, Brickellia (Eupatorieae), Ambrosia, Bahiopsis, Helianthus (Heliantheae), and a few other genera of these tribes, although some records need verification (Foote et al., 1993; Norrbom et al., 2010). The biology of $P$. utilis Stone 1947, used as a biocontrol agent of Ageratina adenophora, has been described in detail (Dodd, 1953; Bess and Haramoto, 1958; Haseler, 1965; Bennett and van Staden, 1986; Freidberg and Mansell, 1995).

Some Procecidochares species have multiple reported host plants, but most, if not all, induce stem or rosette galls usually in the plants of the same genus or tribe. The location of the gall and its presence or absence vary among species or even between overwintering and summer generations.

Procecidochares anthracina (Doane) oviposits between leaflets into the prominent rhizome axillary buds of Solidago californica buried under the soil surface (Goeden and Teerink, 1997); tissues of the bud are intact until the larvae emerge.
Procecidochares utilis lays eggs between the young leaves at the tip of the shoot and the larvae induce a gall along the growing shoot (Bess and Haramoto, 1958); such a location of galls is the most common for the genus (Goeden and Teerink, 1997). Multivoltine gall inducers have a sequential change in choice of plant part from flower head to stem in P. australis Aldrich (Huettel and Bush, 1972) and P. blanci Goeden and Norrbom (Goeden and Norrbom, 2001). The last generation individuals of $P$. australis emerging in the late fall from the flower head galls are the largest; these adults oviposit into overwintering rosette buds; larvae induce slow growth of the galls during the winter, and the generation emerging in the spring has very dense population; these flies lay eggs into axillary stem buds; larvae induce stem galls, but the summer population has very low density due to high mortality (Huettel and Bush, 1972).

Procecidochares blanci is a bivoltine species in southern California in which a "frugivorous" or "flower-head" generation alternates with a "gall-inducing" or "gallicolous" generation on the same host plant, Isocoma acradenia (formerly Haplopappus). Accordingly, the biology of each generation considerably differs. Oviposition into flower heads is in the late summer (September) and pupariation is completed by fall (November), when the adults emerge, mate, and oviposit in axils of axillary buds on last year's branches. The eggs hatch in January, when larval eclosion and gall initiation coincide with axillary bud growth stimulated by the winter rainfall. The first instar larvae of the "gallicolous" generation do not molt during the winter, spring, and summer, as the galls slowly reach their full size about August, when the larvae rapidly molt into the second and third instars, pupariate, and the adults emerge from galls to repeat the reproductive cycle (Goeden and Norrbom, 2001).

Dodson (1987b) described the life cycle of $P$. sp. nr. minuta on Ericameria nauseosa var. bigelovii (as Chrysothamnus) in New Mexico, which has a similar "gallicolous" generation, but recorded no "frugivorous" generation. Norrbom et al. (2010) also recorded only a "gallicolous" generation of P. suttoni Norrbom 2010 on Archibaccharis asperifolia (Astereae) from Guatemala.

These examples clearly show that under conditions of an arid climate, the cycle with gall induction and long larval diapause during the dry period is a more successful strategy than that of the summer "frugivorous" generation, which is more sensitive to drying and parasite pressure and can be lost from the life cycle. This can happen also to species feeding on plants with small flower heads.

Finally, the life cycle of $P$. utilis and its gall anatomy have been summarized in detail by Bennett and van Staden (1986) and Muniappan et al. (2009) as representing the "gallicolous" generation only without being seasonally univoltine in the tropics. The female oviposits batches of 2-23 (average of 7) eggs in the terminal vegetative buds, inserting the aculeus through one of the second pairs of leaves from the top and laying eggs in between the first pair of leaflets. The egg stage lasts 3-5 days depending on the temperature. The first instar larvae move to the base of the young leaves and normally enter the stem between them or occasionally tunnel through the apical meristem. The young leaves are normally damaged as the larvae make their way to the entry point feeding on plant tissue and induce a gall on the stem, occasionally on petioles and/or leaf midribs. Before 
pupation, the third instar larva excavates a tunnel from the larval chamber into the wall of the gall before pupation, leaving the epidermis intact. Preimaginal development from egg to adult emergence lasts 40-60 days. Mating occurs on the same day of emergence; oviposition may commence on the same day and continues for up to 3 weeks, but the majority of the eggs are laid in the first week. Adults live for 2, or rarely 3 weeks (Bess and Haramoto, 1958; Muniappan et al., 2009).

The tunnels left by the larvae are quickly filled by callus cells, which effectively seal the larvae in the plant. After 2 or 3 days, the larvae settle in a region $2-3 \mathrm{~mm}$ from the apical bud where pith cells are still dividing, and vascular tissue is beginning to differentiate. The larvae begin to feed, and almost immediately, the cells adjacent to the larval cavities divide and become orientated with respect to the cavities. Soon they develop into a layer of nutritive tissue composed of six or seven layers of cells that are smaller than the other pith cells, have large nuclei, dense cytoplasm, and are highly mitotic. These cells divide constantly, replace the similar cells consumed by the larvae, and so supplied them with a constant source of nutrition. Once the nutritive layer has developed, the gall becomes visible as a swelling on the stem. The gall continues to grow as the larvae feed. During the growth stage of the gall, the pith cells divide continuously and do not enlarge, and a mass of small gall parenchyma cells is formed. Some of the cells of the cortex become laterally stretched. The collenchymatous thickenings of the cortical cells are less developed than in the normal stem. The normal vascular bundles differentiate, although some are inevitably damaged by the tunneling larvae. In addition, other vascular tissue begins to differentiate in the pith region from procambial cells that had developed near the larval cavities and in close proximity to the normal vascular bundles. The first sign of gall development is evident a week after oviposition when the young leaves at the oviposition site turn crinkled and chlorotic. Three or four days later, the stem bends to about $45^{\circ}$ at the point where oviposition occurred (Bennett and van Staden, 1986). Two weeks from after oviposition, gall initiation becomes evident with red and pink pigmentation. Gall size depends on the number of larvae and the vigor of the plant. With one larva in the gall, the gall size is usually $15 \mathrm{~mm} \times 10 \mathrm{~mm}$, and with multiple larvae (3-11) up to $35 \mathrm{~mm} \times 17 \mathrm{~mm}$ (Bess and Haramoto, 1958). Under favorable environmental conditions, individual stems are attacked repeatedly forming compound galls. Each larva is usually confined to an individual chamber, though in larger galls, the larval chambers may coalesce (Muniappan et al., 2009).

Most univoltine species of Procecidochares are believed to overwinter as first instar larvae (Goeden and Teerink, 1997).

Dracontomyia Becker (=Cecidocharella Hendel), Ostracocoelia Giglio-Tos, and Stenopa with high probability also belong to Cecidocharini sharing with them similar body vestiture and vertically elongated eyes, but the lateral vertical setae are short as in Eutretini. These three genera share broad wings with an apically widened, almost triangular discomedial cell and also strong costal spurs, vertical elongated eyes, shining scutellum, and sparse scalelike mesonotal setulae. Two of the three Nearctic species of Stenopa feed in Senecio spp.: S. vulnerata (Loew) induces galls in buds or young twigs in the lower part of the host plant (Novak and Foote, 1975), and the larva of S. affinis Quisenberry eats the parenchyma in rosettes (underground stem and upper root) without proliferation of their tissue (Goeden and Headrick, 1990); the host plant of S. mexicana Norrbom 2010 is not known.

Ostracocoelia mirabilis Giglio-Tos was reared from an elongated, tapered stem gall on Ageratina mairetiana (Eupatorieae) in Mexico. The biology of the mainly Neotropical genus Dracontomyia is poorly known. Dracontomyia borrichia larvae feed in flower heads of Borrichia frutescens (Bush and Huettel, 1970), whereas Norrbom et al. (2010) reared D. footei Aczél from stem galls on Baccharis salicifolia (Astereae) in Peru. Its larvae breed in apical galls on slender branches $2-3 \mathrm{~mm}$ in diameter, apparently killing the apical meristem as there was no growth of the branches beyond the galls, one larva per gall (Norrbom et al., 2010).

To summarize the biology and distribution of the Cecidocharini, it can be hypothesized that they originated from non-gall-inducing flower head infesting ancestors similar to Gymnocarena. They passed through the bottleneck of aridization of the southern North American climate, leading to domination of the shrubs, semi-shrubs, and rhizome perennial Astereae with small flower heads not providing enough food for the larvae to survive the dry summer season. Oviposition between leaflets of stem buds does not require any additional modifications to the structure of the ovipositor aculeus, which is similar in appearance to those of the Xyphosiini and Gymnocarena. This resulted in the success of the flower head feeders able to induce galls in certain plant species with a proliferative response to chemical stimuli and a shift from ancestral plants unable to produce galls. The gall inducers had an advantage over the non-gall-inducing species as they could evolve multivoltine cycles with a sequential change in choice of plant part from flower head to stem, as in Procecidochares australis. Further reduction in the flower head generation resulted in a pure stem or rhizome gall-inducing strategy, with the preimaginal stages surviving unfavorable conditions within the galls.

Even if primary association with flower heads is hypothesized from its occurrence in most Lower Tephritinae, the strategy of larval feeding of Cecidocharini, in general, appears to be highly plastic and with a tendency to revert, and lacks morphological adaptations to the female aculei for deep penetration, piercing, or cutting of plant tissues.

Cecidocharini obviously immigrated into South America through the Isthmus of Panama and then along the Andes since "the Great American Biotic Interchange" began around 2.7 million years ago. This gave rise to predominantly South American genera, such as Cecidochares, Dracontomyia, Hetschkomyia, and Neorhagoletis.

\section{Tomoplagia Group of Genera (Acrotaeniini Partim)}

This group includes Tomoplagia Coquillett (59 species in South and Central America, and 2 in North America), Polionota Wulp (eight species in South and Central America), Neotaracia Foote (three species in South and Central America), and Caenoriata 
Foote (one species in Brazil). Host plants and larval feeding have been described for Caenoriata pertinax, which feed in flower heads of Piptocarpha (Vernonieae) (Norrbom and Prado, 2006), Neotaracia imox, which feeds in flower heads of a species of Synedrella (Heliantheae) (Norrbom et al., 2013), two species of Polionota that feed in stems (one in Coreopsis), and multiple species of Tomoplagia, which infest predominantly large or moderate-sized flower heads of Vernonia and allied genera of the tribe Vernonieae, as well as some Mutisieae, and other tribes; a few species induce galls in flower heads or on stems.

Larval feeding has been described in detail only for T. cressoni Aczél from California (Goeden and Headrick, 1991). Eggs are inserted between or within floral tubes of immature florets by a female from an external position at the apex of a head after anthesis, and not by puncturing the phyliaries laterally with her ovipositor to gain access to the interior of a head (the aculeus is blunt). The first instar larva, upon hatching, tunnels into a floral tube, which causes the basally attached ovule to abort. The larva next transfers to, and mines one or two more, floral tubes. As a second instar, the larva mines one to four adjacent ovules and then proceeds to score the receptacle. The third instar excavates a cuplike depression in the receptacle surface without observable tissue proliferation (no gall formation). It feeds by imbibing sap transported to the receptacle via the vascular tissues, which suffuse this nurse tissue for the developing florets, as was described by Romstock (1987) for Tephritis. The imbibition of sap represents the main mode of feeding for third instars of Tomoplagia cressoni. This feeding is obligatory (or at least consistent) even among solitary larvae of many other flower head-infesting Tephritidae (Goeden and Headrick, 1991). Schwitzgebel and Wilbur (1943) reared T. obliqua (Say) "from seeds" of ironweed, Vernonia inferior, in Kansas; larvae obviously feed on the ovules and achenes, destroying all seeds in a flower head. Hosts are known for 28 other species of Tomoplagia from South America, mostly reared from flower heads without induction of galls (Prado et al., 2002, 2004; Savaris et al., 2015).

Some cecidogenous Tomoplagia are known, among them, T. vernoniae Hering 1938 and T. rudolphi Lutz and Lima from Brazil, which induce polythalamous stem galls. Tomoplagia rudolphi was reported to oviposit in shoot apical meristems, but without indication of whether they pierce tissues or lay eggs between leaflets of buds. As eggs hatch, the larvae feed on cells of the medullar parenchyma, and gall tissue proliferates surrounding the larvae, resulting in a globulous gall. The larva excavates a hole through which the adult leaves the gall; after pupation, the adults emerge 15-20 days later to begin a new reproductive cycle (Andrade et al., 1995; Silva et al., 1996; Savaris et al., 2019).

Based on 16S DNA analysis, Han et al. (2006) recovered Tomoplagia and Pyrgotoides Curran (as Gerrhoceras) from Costa Rica, Panama, Ecuador, Peru, and Bolivia as a monophyletic lineage despite the latter genus being formerly assigned to Dithrycini of the "Higher Tephritinae" (Korneyev, 1999b; Korneyev et al., 2005). Pyrgotoides peruvianus (Korytkowski, 1976) forms large stem galls on Ophryosporus peruvianus and Ageratina pentlandiana (Eupatorieae) (Korytkowski, 1976; Norrbom et al., 2013). Tentatively, the genus Agallamyia
Norrbom, similar to Pyrgotoides, also belongs here; the larvae of Agallamyia pendula Norrbom 2010 induce a large spherical stem gall up to $2.5 \mathrm{~cm}$ in diameter on Perymenium ghiesbreghtii and $P$. grande (Heliantheae). The gall is unusual in being mostly hollow, with the single larva loose inside, differing from the galls of Cecidocharini (Norrbom et al., 2010).

The center of diversity of the Tomoplagia group lies in South America. The group, therefore, entirely evolved in the Neotropics from an ancestor that invaded across the Isthmus of Panama after the "Great American Biotic Interchange" ( $<2.7$ Mya); some taxa could have entered through the island chain that existed earlier or dispersed across the gap. The two Nearctic Tomoplagia species are believed to be quite recent invaders, which possibly migrated here in the Pleistocene.

\section{“HIGHER TEPHRITINAE” + TERELLIINI}

Lineage 2, the second major branch of Tephritinae, has a basal bifurcation into a monophyletic Lineage 10, which corresponds to the tribe Terelliini, and Lineage 9, which corresponds to the rest of the "Higher Tephritinae." These lineages do not share any morphological synapomorphies, and the monophyly of this cluster was only supported by the 50 and $90 \%$ majority rule consensus trees derived from Bayesian analysis of the 16S rRNA gene sequences using the GTR $+\mathrm{I}+\mathrm{G}$ evolutionary model and the posterior probability $\mathrm{Pp}=97$ (Han et al., 2006: Figures 3, 4).

\section{Terelliini}

Phylogenetic analyses based on morphology (Korneyev, 1999b; Korneyev et al., 2005) recover Terelliini as the basalmost lineage, the sister group to all other Tephritinae, based primarily on the plesiomorphic state of several genitalic characters that Terelliini share with such outgroups as Dacinae and Trypetinae. Most species occur in the Palaearctic Region, with only three species native in the Nearctic Region, six Oriental and nine Afrotropical species, all of which are believed to have resulted from invasions from the Palearctic in the Pliocene to Africa and in the Pleistocene to North America via the Bering Land Bridge. Terelliini are associated mostly with Cardueae, with a few species feeding in Cichorieae and Vernonieae, ovipositing between young florets and mining several adjacent ovules, and then eating the receptacle and achenes, or even mining the stems, without tissue proliferation and no gall induction.

According to Han et al. (2006), the rest of the "Higher Tephritinae" are subdivided into two lineages: Lineage 11, which corresponds to the "Higher Tephritini" of the Nearctic and Neotropical Regions, and Lineage 12, which is represented by the species assigned to the tribes Tephritini, Platensinini (=Oedaspidini), and Tephrellini (=Aciurini), which have their centers of diversity in the Afrotropical Region, with numerous genera of Old World or subcosmopolitan distribution.

\section{The New World "Higher Tephritini"}

Molecular-based phylogenetic analysis by Han et al. (2006) recovered a complex of genera previously dispersed among the tribes Dithrycini, Euarestini, Tephritini, and Eutretini due to their morphological and ecological similarity (Korneyev, 1999b; 
Korneyev et al., 2005) as a well-supported monophyletic group (Lineage 11 on Figure 1).

This group includes several lineages that include no or very few cecidoginous species (Euaresta, Paracantha, Dictyotrypeta, Dyseuaresta, Neotephritis, and their relatives), as well as other taxa completely (or mostly) represented by specialized gallinducers.

\section{Euarestini}

The tribe Euarestini Hering 1947 corresponds to the single genus Euaresta Loew with 16 species almost equally distributed between the Neotropical and Nearctic Regions associated with Heliantheae Ambrosiae: Ambrosia and Xanthium (Foote et al., 1993, Norrbom, 1993). They may be related to the species of the Euarestoides group of genera (Foote et al., 1993) assigned to Tephritini, but additional molecular-based phylogenetic studies need to be pursued. Euaresta larvae feed in ovules of the female plant or staminate florets of the male plant without inducing galls.

\section{Eurostini}

Monophyly of Eurostini is well-supported by at least one synapomorphy (long narrow surstyli). All the species of known biology are associated with asteraceous perennial herbs and shrubs of the Astereae subtribe Solidagininae (Wasbauer, 1972; Wangberg, 1978, 1980, 1981; Novak and Foote, 1980, Foote et al., 1993). The relatively large-sized species of Eurosta occur mainly in the humid areas of eastern North America and infest mesic species of Solidago, whereas Aciurina and Valentibulla induce galls mainly on xeric Chrysothamnus, Ericameria, and Gutierrezia plants in semiarid western North America. The two main trends in evolution of the Eurostina are apparently adaptation to mesic and xeric plants, which have resulted in the Eurosta and Aciurina+Valentibulla lineages, respectively (Korneyev et al., 2005).

Tauber and Tauber (1967) observed the female of Aciurina ferruginea (Doane) or A. michaeli Goeden and Teerink 1996 ovipositing in the plant exudate (resin) covering the axillary buds of Chrysothamnus viscidiflorus. Goeden and Teerink (1996a) described the biology of both species. Their eggs are laid singly in each axillary bud in August. The plant tissue is not pierced, and only the larva initiates and sustains gall formation by the plant. The first instar larva feeds downward into the bud during September-October. It overwinters in a gall just beginning growth. The second instar larva was recorded in May, and the differences between the galls induced by the two species were clear. The galls of A. ferruginea are leafy, "wooly," covered by numerous short leaflets, and have a unique appearance among tephritid galls, whereas those of A. michaeli are almost leafless, and "beaked." Larvae molt into the third instar in mid-June. The inner surface of the gall is shallowly pitted and thinly coated with sap, on which the larva feed within a parenchymatous, ellipsoidal core. In mid-July, the third instar larva occupies a $4.5 \mathrm{~mm} \times 2 \mathrm{~mm}$ basal ovoidal locule and excavates a thin, circular, epidermal window. The larvae pupariate within the gall in July. Adults emerge later in July, mature in 10 days, mate, and oviposit into newly formed basal axillary buds on current-year branches (Goeden and Teerink, 1996a).
Similar univoltine life cycles were described for A. michaeli, A. idahoensis Steyskal, and A. semilucida (Bates), which also infest Chrysothamnus viscidiflorus in Sierra Nevada, differing seasonally, altitudinally, in wing pattern, and gall appearance (Goeden and Teerink, 1996a,b,c), which is a good case for study of sympatric and parapatric speciation.

Dodson and George (1986) described different types of galls on Ericameria nauseosa by Aciurina bigeloviae (Cockerell) and A. trixa Curran and found that there is a limited, unidirectional gene flow between them and discussed a scenario of their divergence.

Aciurina thoracica Curran induces axillary bud galls on branches of three species of Baccharis (Astereae). It emerges from January through March and oviposits through April in southern California; adults emerge through June-October triggered by rainfall, and may be delayed until March the next year; the second generation is possibly facultative (Headrick and Goeden, 1994).

Wangberg (1978), Dodson (1987a), and Goeden et al. (1995a) described the biology of Valentibulla steyskali Foote, $V$. dodsoni Foote, and V. californica (Coquillett). Females of the latter species oviposit into or near prominent axillary buds into a current or preceding year's branch of Ericameria naseosa. The hatched larva tunnels into the branch without forming a visible gall and apparently feeds on sap. Before pupation, the larva excavates a circular, epidermal window above one end of its cell, through which the adult fly exits; the descriptions of galls by Wangberg (loc. cit.) were considered confusing (Goeden et al., 1995a).

Novak and Foote (1980) and Wangberg (1980) described most known galls of Eurosta on Solidago. Univoltine (as possibly all species of this genus) Eurosta comma (Wiedemann 1830) forms galls on rhizomes of Solidago juncea and S. rugosa. Adults emerge in September and lay single eggs into young buds or shoots at the base of the host plant in September, tunelling through the bud or young stem to the rhizome, where induction of the tuberose gall starts. The second instar larva overwinters in a small gall under the soil level. In April-June, gall induction continues, and in June, they reach full size $(15 \mathrm{~mm} \times 7.5 \mathrm{~mm})$, containing a single larva. The third instar lasts 85-90 days; before pupation in August, the larva tunnels an exit window covered with a thin epidermis layer. Each plant rhizome has one to four galls $2 \mathrm{~cm}$ below soil level [Novak and Foote (1980): as "Eurosta elsa", misid.].

Eurosta cribrata (Wulp 1867), another univoltine species, forms galls on young stems of Solidago juncea and $S$. sempervirens. Adults emerge in mid-May through early June and oviposit into young stem buds at the soil surface in June, tunelling through the bud or young stem to the rhizome, where induction of a gall starts instead of aborted shoot growth forming a $20 \mathrm{~mm} \times 5 \mathrm{~mm}$ bud gall covered with scales of transformed leaflets. The second instar larva overwinters in a small gall under the soil level. In April-June, gall induction continues, and in June, they reach full size $(15 \mathrm{~mm} \times 7.5 \mathrm{~mm})$ containing a single larva molting into the third instar in early October and pupariating in November. Each plant rhizome has one to four galls $2 \mathrm{~cm}$ below the soil level [Novak and Foote (1980): as Eurosta reticulata].

Eurosta solidaginis (Fitch 1855) forms the goldenrod ball gall on the stem of Solidago canadensis and S. gigantea, with the preferred host varying in different geographical regions (Novak and Foote, 1980). Adults emerge from overwintering galls in 
late May or early June. After mating, adult females lay eggs in the folded leaves of the terminal bud. The hatched first instar larva tunnels down through the folded leaves of the terminal bud into stem tissue generally right below; the gall grows during 3-4 weeks from the $3 \mathrm{~mm}$ stem into a gall up to $30 \mathrm{~mm}$ in diameter. During the course of gall development, the first instar larvae do not increase greatly in size. Larvae continue to grow after gall growth has ceased, reaching a maximal size of about 3.5 months after hatching. Larvae overwinter as third instars and pupariate in the spring (Uhler, 1951). As gall develops, bands of meristematic tissue form in the pith and then split into strands of meristematic tissues that radiate from the central pith region surrounding the larval chamber outward to the fasicular cambia of the vascular bundles. In a mature gall, some of the cells of the meristematic strands show reticular thickenings that stain more deeply and resemble the thickenings of the walls of some vessel cells (Beck, 1947). Stoltzfus (1989) discovered a phenomenon of non-gall-forming E. solidaginis infesting Solidago canadensis, which is of great interest for population genetics. Among the seven species of Eurosta, all the possible aspects of gall-inducing physiology, criobiology, phenology, evolution, morphology, and ecology are best studied for E. solidaginis, a favorite model for gall studies (Abrahamson and Weis, 1997). The larva of $E$. solidaginis, which overwinters inside the gall at a height $30-50 \mathrm{~cm}$ above ground, was found to have elaborated freeze tolerance and is used as a model to study physiological and biochemical mechanisms of such tolerance (Irwin et al., 2001; Sandro and Lee, 2006).

The tribe Eurostini is comprised exclusively by gall-forming species, which oviposit into (or near) axillary buds, with the larva then tunneling into branches or shoots inducing formation of the galls. This type of cecidogeny evolved from primarily non-galling forms like in the sister group (Euarestini) and independent from the other gall-forming lineages of Tephritinae (Myopitini, Cecidocharini, Platensinini, and Tephritini).

\section{Eutretini (Other Than Eutreta)}

This lineage has poor support and, thus, may actually represent a remander of the tribe Eutretini sensu Korneyev (1999b) without Euaresta, Eurostini, and Eutreta. The genera in Lineage 14 are morphologically variable and consist of non-cecidogenous New World genera feeding in the flower heads of various asteraceous plants, but predominantly belonging in the tribe Heliantheae with larval feeding as far as known, within achenes or within the receptacle by imbibing sap. Some species formerly assigned to Acrotaeniini may actually belong here, but confirmation of their relationships needs further molecularbased phylogenetic analysis.

The lineage shown here as Dyseuaresta Hendel actually represents a complex of Neotropical genera (Dyseuaresta group), which includes also Pseudoedaspis Hendel and Lamproxynella Hering.

\section{The Genus Eutreta}

This genus includes 35 or more species almost equally distributed between North and South America and at least another 20 undescribed species. All species of known biology are gall formers, the Nearctic species predominantly on plants belonging to the Astereae Solidaginae or Anthemideae (mostly Artemisia) (Stoltzfus, 1977; Foote et al., 1993). Many Neotropical (and E. xanthochaeta Aldrich 1923 in Mexico and Central America) species likewise attack Asteraceae, but a few infest Lamiaceae, Loganiaceae, Plantaginaceae, Solanaceae, or Verbenaceae plants (Norrbom et al., 2010, Warton and Norrbom, 2013), including Lantana, a noxious invasive weed (Cilliers and Neser, 1991). The Artemisia-infesting Eutreta diana (Osten Sacken 1877) and E. simplex Thomas 1914 induce monothalamous galls within axillary buds on the branches or terminal buds of succulent young shoots arising from the rhizome. Most North American species are known to be univoltine. Females oviposit into the buds, deeply cutting the tissues with their sharp, serrate aculeus. The first instar larva then burrows into the bud, which becomes slightly modified only in the beginning of winter, as the second instar larva starts feeding; full growth of the gall begins only in early spring. Phenology of oviposition in different species depends on the formation of buds in spring or autumn (Goeden, 1990a,b). Other species were reported to induce rhizome or crown galls on species of Ageratina, Ambrosia, Bidens, Chrysanthemum, Dahlia, Engelmannia, Erechtites, Erigeron, Helianthus, Jacobaea, Podachaenium, Ratibida, Solidago, Squamopappus, Verbesina, Vernonia, or Wedelia, some bivoltine species forming rhizome or stem node galls on young shoots in spring, possibly shifting to other host plants and inducing axillary bud galls on branches. Although some species are specialists (e.g., those utilizing Artemisia), various species have been reported to attack multiple genera of Asteraceae and are relative generalists, which may have predisposed some of the Neotropical species to shift to host plants in the Verbenaceae and several other non-asteraceous families. The South American species E. sparsa (Wiedemann 1830) and the Mesoamerican species E. xanthochaeta Aldrich 1923 form monothalamous galls on young shoots of Lantana, Lippia, Stachytarpheta, and Verbena (Verbenaceae), whereas E. parasparsa Blanchard utilizes Solenostemon (Lamiaceae), and E. margaritata Hendel utilizes Penstemon (Plantaginaceae) (Stoltzfus, 1977; Warton and Norrbom, 2013). The Nearctic species show more generalized morphological characters and higher morphological diversity, so the genus probably originated in North America (Stoltzfus, 1977) and then invaded South America in the Pliocene as the Isthmus of Panama was formed.

\section{Xanthomyia Phillips}

This poorly known Holarctic genus has two northern Nearctic, one Far East Asian, and one transpalearctic species. The latter, $X$. alpestris (Pokorny), occurs mostly in alpine areas and northern tundras, collected usually in association with Erigeron or Aster plants, but never reared from the flower heads. It has a flat piercing aculeus of the ovipositor similar to that of Eutreta and, thus, may form bud galls, similar to some species of the latter genus. Xanthomyia is also believed to have a Nearctic origin and apparently invaded Asia during the Pleistocene through the Bering Land Bridge. The current distribution of the only transpalearctic species, $X$. alpestris (Pokorny) is strongly 
fragmented (Alps, Tien Shan, north of European Russia, and north of East Siberia).

\section{Dithrycini}

Here, I restrict the concept of this tribe to the Palaearctic genus Dithryca Rondani, as its relationships with either Eurostini or Platesinini (=Oedaspidini) have not been confirmed by molecular-based phylogenies.

The genus includes two distantly related species, Dithryca guttularis (Meigen 1826) widespread from Britain and France to West Siberia and D. guttulosa (Loew 1869) from the Iberian Peninsula, inducing rhizome and stem galls on Achillea millefolia and Santolina rosmarinifolia (Anthemideae), respectively (Korneyev, 2002).

\section{The Old World "Higher Tephritinae"}

The monophyly of Lineage 12 (and therefore of the whole tribe Tephritini) has not yet been supported by molecular analysis, as Han et al. (2006) recovered its component taxa as a polytomy of lineages represented by the Tephritis group of the Tephritini, Platensinini, and Tephrellini (Lineage 15), on one hand, and the Campiglossa and Sphenella group of species (Lineage 16), on the other. The genus Hendrella Munro (see Korneyev, 1989), originally assigned to the "Dithrycini," was recovered here as a separate lineage in the polytomy.

Unlike the New World groups, the biology of the Old World gall formers is very poorly documented, and at most, general descriptions of the galls exist, without detailed analyses of phenology and life cycles.

\section{Tephritis Group of Genera}

Norrbom et al. (1999): Trupanea group of genera; Korneyev (1999b); Merz (1999): Tephritis group of genera.

The monophyly of this group was partly supported by the five-gene molecular phylogenetic analysis of Korneyev et al. (2020) and partly by the morphology-based analysis of Merz (1999). The core of genera of this group occurs in the Afrotropical region, Mediterranean region, and the Near East, predominantly in savannas and mountain grassy biomes. Several genera occur far beyond this area: the predominantly Holarctic Tephritis, the subcosmopolitan Trupanea, and a few endemic Australasian genera (Austrotephritis and possibly others). Most genera assigned here, including the distant or sister groups, such as Acinia Robineau-Desvoidy, Actinoptera Rondani, and Spatulina Rondani, are represented mostly by flower head feeding on non-cecidogenous species with a few cases of gall inducers such as Spathulina, Euarestella Hendel, Multireticula Merz (Merz, 1999), and Heringina Aczél, all forming bud galls on various Gnaphalieae, as well as a few Actinoptera. The most plausible scenario is that Gnaphalieae plants are able to respond to larval feeding by gall induction and that erroneous oviposition into buds happens often in species with small, fast blossoming flower heads, which are, thus, less available for oviposition. Occasionally, flower head galls or swellings of the receptacle preventing opening of flower heads infested by larvae are produced by many Tephritis and a few Trupanea (Freidberg, 1984).

\section{Platensinini (=Oedaspidini)}

The concept of this tribe has been intuitively changed by Hancock (2001) to combine the Oedaspis group of genera (Hyalopeza, Liepana, and Oedaspis) and the Platensina group of genera (Australasinia Hancock, Bezzina Munro, Collessomyia Hardy and Drew, Euthauma Munro, Malaisinia Hering, Platensina Enderlein, and Pseudafreutreta Hering). A few gall formers are known for the latter group, among them Malaisinia variegata (Radhakrishnan) inducing stem galls on Inula cappa (Inuleae) (Radhakrishnan, 1984).

The Oedaspis group is the most specialized group represented exclusively by gall-inducers, which are associated mostly with Plucheae and Gnaphalieae, Inuleae s.str. and Senecioneae. Palearctic species of Oedaspis are associated exclusively with Artemisia (Anthemideae), forming bud galls on subterrestrial and axillary buds, which are very similar in their morphology to those of Procecidochares and Eutreta, showing that the gall shape depends mostly on the plant response to the larval influence rather than being the result of fly evolution. Most Palaearctic Oedaspis, which live in subarid and arid climates, have aphagous adult flies with a reduced proboscis and very well-developed fat body developed during larval feeding. It is not clear if the females oviposit into young buds in late autumn or are able to overwinter by hibernation and oviposit in the spring, another possible explanation for such extensive storage of fats.

Similar to the South American Eutreta, some Australian Oedaspis species induce galls also on non-asteraceous host plant, namely, stem galls on Dampiera, Goodenia, Scaveola, and possibly Lechenaultia (Goodeniaceae) (O. goodenia Hardy and Drew 1996, O. whitei Hardy and Drew 1996, and possibly $O$. continua Hardy and Drew 1996, and O. semihyalina Hardy and Drew 1996) and show no definite connections with any of the known groups.

For more details on gall occurrence and phylogenetic relationships within the Oedaspis group, see Freidberg (1984, 1998) and Korneyev et al. (2005).

\section{Tephrellini (=Aciurini)}

Another predominantly palaeotropical (mostly Afrotropical) group related to the Tephritis group and the Platensinini, this group also evolved due to shifting from flower head feeding on Asteraceae to feeding on single ovules mainly inside Lamiaceae flowers. This also could have happened when favorable asteraceous hosts with large flower heads were lost in the grassy biomes of the Paleotropics, which caused such a shift to new dominant hosts. No galls are induced by species in this group.

\section{Hendrella Munro and Placaciura Hendel}

The strictly Palaearctic genus Hendrella and the closely related Placaciura are inducers of axillary bud galls on Artemisia, very similar to those of Palaearctic Oedaspis. The molecular analysis of Han et al. (2006) recovered it as a basal lineage rather than a part of the Oedaspis group, suggesting that, here, gall induction may have evolved independently. 


\section{Campiglossa and Sphenella Groups of Genera}

Lineage 16 is represented by two possibly monophyletic generic complexes represented by both flower head non-cecidogenous species and by bud, rhizome, and stem gall inducers. As the natural history and gall morphology have not been examined and described carefully for many species, I only mention some of them.

\section{Campiglossa Group}

The group includes Antoxya, Mesoclanis, Scedella, Oxyna, Campiglossa, Lethyna, and Desmella. The Holarctic genus Oxyna Robineau-Desvoidy is associated exclusively with Anthemideae hosts (Artemisia, Achillea, Leucanthemuma, and Tanacetum). Two Palaearctic species, namely, O. nebulosa (Wiedemann) and O. flavipennis (Loew), are known to induce rhizome galls. Their adults are active in July and August, and probably oviposit in the fall into the young buds or shoots on the rhizome. The North American O. aterrima was described to oviposit into terminal buds on Artemisia tridentata similar to those of Eurosta, containing a single larva tuneling into the bud and inducing gall formation in the autumn and then overwintering as the third instar larva (Goeden, 2002a).

At least five Palaearctic species of Oxyna, O. parietina (Linnaeus), O. obesa (Loew), O. albipila (Loew), O. lutulenta (Loew), and O. stackelbergi V. Korneyev also oviposit into young terminal buds on various species of perennial Artemisia (in April or May) and tunnel inside the stem without gall induction (Korneyev and Evstigneev, 2013).

Another Nearctic species, O. palpalis (Coquillett) oviposits into the galls of Rhopalomera florella Gagné (Cecidomyiidae) on Artemisia tridentata otherwise developing similar to the gall inducing of O. aterrima (Goeden, 2002b).

The natural history of all other Palaearctic species remains unknown. The two Central Asian species associated with Artemisia dracunculus, Oxyna guttatofasciata (Loew), and O. dracunculina Richter have never been found in the stems above ground level. It can be assumed that their larvae live in underground galls.

The Nearctic species of Oxyna apparently evolved after invasion of the Asian species through the Bering Land Bridge in the Pleistocene.

The subcosmopolitan genus Campiglossa Rondani $(=$ Paroxyna,$=$ Gonioxyna,$=$ Homoeotricha , and $=$ Dioxyna $)$ is represented by many local subendemic or endemic groups of species in each zoogeographic region. Most Campiglossa are multivoltine flower head feeders, and only a few of them are known to have gall-inducing larvae.

Campiglossa grandinata Rondani induces terminal bud stem galls on Solidago (Astereae), and C. argyrocephala (Loew) induces similar galls on Achillea ptarmica (Anthemideae). The Asian species formerly assigned to the genus Homoeotricha all are associated with Gnaphalieae plants, but have never been reared from aboveground parts of the plants and are believed to form bud or rhizome galls.

\section{Sphenella Group}

This group includes over 50 species belonging to six or seven genera forming a well-defined cluster having an Old World distribution associated with plants of the tribe Senecioneae. The group was reviewed by Freidberg (1987) and Freidberg and Hancock (1989), then redefined in the strict sense by Korneyev (1999b). Most Sphenella, Oedosphenella (=Bevismyia), Orotava, Afrotropical species assigned to Paratephritis, and possibly Telaletes feed as larvae in flower heads, sometimes inducing the achenes to swell (Munro, 1957), but no detailed descriptions of their galls are available. Known Parafreutreta and the East Asian species of Paratephritis form large polythalamous stem galls, which can be spherical to spindlelike. Depending on their numbers, larvae pupariate in a common chamber or in separate chambers, with a single exit hole from the gall (Munro, 1953; Kandybina et al., 1967). Monophyly of the group of gall-inducing species remains unresolved. Aculeus shape is similar in the gallicolous Pseudotephritis transitoria (Rohdendorf) and species ovipositing into flower heads, although conspicuously narrower and longer in $P$. transitoria, but not sharply pointed at its apex. Ovipositional behavior has not been described.

\section{DISCUSSION}

The zoogeography of Tephritinae tribes and groups of genera taxonomically modified by reclassifying similar but nonrelated taxa based on molecular phylogetic analysis shows that cecidogeny arose independently within the Myopitini (in three lineages), Cecidocharini, Tomoplagia group of genera, Eurostini, Eutreta, Tephritis group of genera, Platensinini, Campiglossa group of genera, and Sphenella group of genera. This occurred between the complete disappearance of the Atlantic Land Bridge and the rise of the Isthmus of Panama, and more or less synchronously on the African and North American continents, via invasion of certain derivative genera into new regions together with their gall-producing host plants. The most probable time of these events is the late Miocene or early Pliocene. Cecigogeny multiple and independent evolution was due to the shift to the new dominant host plants that had smaller flower heads, were sensitive to larval feeding, and capable of tissue proliferation, thus, providing the larvae with shelter from unfavorable climatic conditions like temporary aridization in the grassy biomes in the Nearctic and Afrotropics in the late Miocene or early Pliocene.

\section{DATA AVAILABILITY STATEMENT}

The original contributions presented in the study are included in the article/supplementary material, further inquiries can be directed to the corresponding author/s.

\section{AUTHOR CONTRIBUTIONS}

The author confirms being the sole contributor of this work and has approved it for publication. 


\section{REFERENCES}

Abrahamson, W. G., and Weis, A. E. (1997). Evolutionary ecology across three trophic levels: goldenrods, gallmakers, and natural enemies. Monogr. Popul. Biol. 29, xiii +456 .

Aczél, M. L. (1950). A revision of the genus 'Xanthaciura'Hendel (Trypetidae. Dipt.) based on Argentine species. Acta Zool. Lilloana (1949) 8, 111-146.

Aczél, M. L. (1952). Further revision of the genus Xanthaciura Hendel (Trypetidae, Dipt.). Acta Zool. Lilloana 10, 245-280.

Andrade, G. I., Silva, I. M., Fernandes, G. W., and Scatena, V. L. (1995). Aspectos biológicos das galhas de Tomoplagia rudolphi (Diptera: Tephritidae) em Vernonia polyanthes (Asteraceae). Rev. Bras. Biol. 55, 819-829.

Arnold-Rinehart, J. (1989). Histologie und Morphogenese von Urophora- und Myopites Blütenkopfgallen (Diptera: Tephritidae) in Asteraceae. Doctoral dissertation, University of Bayreuth, Germany: [1-5] + [1-99].

Beck, E. G. (1947). Some Studies on the Solidago Gall Caused by Eurosta solidaginis (Fitch). PhD thesis, University of Michigan.

Bennett, P. H., and van Staden, J. (1986). Gall formation in croftonweed, Eupatorium adenophorum Spreng. (syn. Ageratina adenophora), by the Eupatorium gall fly Procecidochares utilis Stone (Diptera: Trypetidae). Aust. J. Bot. 34, 473-480. doi: 10.1071/BT9860473

Bess, H. A., and Haramoto, F. H. (1958). Biological control of pamakani, Eupatorium adenophorum, in Hawaii by a tephritid gall fly, Procecidochares utilis. I. The life history of the fly and its effectiveness in the control of the weed. Proc. Teenth Int. Congess Entomol. (1956) 4, 543-548.

Burkhardt, B., and Zwölfer, H. (2002). Macro-evolutionary trade-offs in the tephritid genus Urophora: benefits and costs of an improved plant gall. Evol. Ecol. Res. 4, 61-77.

Bush, G. L., and Huettel, M. D. (1970). Cytogenetics and description of a new North American species of the neotropical genus Cecidocharella (Diptera: Tephritidae). Ann. Entomol. Soc. Am. 63, 88-91. doi: 10.1093/aesa/63.1.88

Cilliers, C. J., and Neser, S. (1991). Biological control of Lantana camara (Verbenaceae) in South Africa. Agric. Ecosyst. Environ. 37, 57-75. doi: 10.1016/0167-8809(91)90139-O

Denk, T., Grímsson, F., and Zetter, R. (2010). Episodic migration of oaks to Iceland: evidence for a North Atlantic "Land Bridge" in the Latest Miocene. Am. J. Bot. 97, 276-287. doi: 10.3732/ajb.0900195

Dodd, A. P. (1953). Observations on the stem gall fly of pamakani, Eupatorium glandulosum. Proc. Hawaiian Entomol. Soc. 15, 41-44.

Dodson, G. (1987a). Biological observations on Aciurina trixa and Valentibulla dodsoni (Diptera: Tephritidae) in New Mexico. Ann. Entomol. Soc. Am. 80:494-500. doi: 10.1093/aesa/80.4.494

Dodson, G. (1987b). Host-plant records and life history notes on New Mexico Tephritidae (Diptera). Proc. Entomol. Soc. Wash. 89, 607-615.

Dodson, G., and George, S. B. (1986). Examination of two morphs of gall-forming Aciurina (Diptera: Tephritidae): ecological and genetic evidence for species. Biol. J. Linnean Soc. 29, 63-79. doi: 10.1111/j.1095-8312.1986.tb01771.x

Donoghue, P. C. J., and Smith, M. P. (eds.). (2004). Telling the Evolutionary time. Molecular Clocks and the Fossil Record (Systematics Association Publication no. 66). Boca Raton, FL: CRC, viii +288

Foote, R. H., Blanc, F. L., and Norrbom, A. L. (1993). Handbook of the fruit flies (Diptera: Tephritidae) of America north of Mexico. Ithaca, NY: Comstock Publishing Associates, xii +571 .

Freidberg, A. (1980). On the taxonomy and biology of the genus Myopites (Diptera: Tephritidae). Israel J. Entomol. (1979) 13, 13-26.

Freidberg, A. (1984). “Chapter 6: Gall Tephritidae," in Biology of Gall Insects, ed. T. N. Ananthakrishnan (New Delhi: Oxford and IBH Publishing Co.), 129-167.

Freidberg, A. (1987). Orthocanthoides aristae, a remarkable new genus and species of Tephritidae (Diptera) from Mt. Kenya. Ann. Natal Museum 28, 551-559.

Freidberg, A. (1998). "Tephritid galls and gall Tephritidae revisited, with special emphasis on myopitine galls," in The Biology of Gall-Inducing Arthropods, eds. G. Csóka, W. J. Mattson, G. N. Stone, and P. W. Price. USDA Forest Service, North Central Research Station, General Technical Report NC-199, pp. 36-43.

Freidberg, A. (2002). Systematics of Schistopterini (Diptera: Tephritidae: Tephritinae), with descriptions of new genera and species. Syst. Entomol. 27, 1-29. doi: 10.1046/j.0307-6970.2001.00162.x
Freidberg, A., and Hancock, D. L. (1989). Cryptophorellia, a remarkable new genus of Afrotropical Tephritinae (Diptera: Tephritidae). Ann. Natal Museum 30, 15-32.

Freidberg, A., and Mansell, M. W. (1995). Procecidochares utilis Stone (Diptera: Tephritidae: Oedasipidini) in South Africa. Afr. Entomol. 3, 89-91.

Freidberg, A., and Norrbom, A. L. (1999). "A generic reclassification and phylogeny of the tribe Myopitini (Tephritinae)," in Fruit flies (Diptera: Tephritidae): Phylogeny and Evolution of Behavior, eds. M. Aluja, and A. L. Norrbom (Boca Raton, FL; London; New York, NY; Washington, DC: CRC Press), 581-627.

Freidberg, A., Zonstein, I., and Friedman, A.-L.-L. (2020). Tanzanimyia, a new Afrotropical genus of Schistopterini with four new species (Diptera: Tephritidae: Tephritinae). Israel J. Entomol. 50, 19-39. doi: $10.5281 /$ zenodo.3872861

Gentilini, G., Korneyev, V. A., and Kameneva, E. P. (2006). Fossil tephritoid flies (Diptera: Pallopteridae, Ulidiidae, Tephritidae) from the Upper Miocene of Monte Castellaro, Italy, and a review of fossil European tephritoids. Instrum. Biodivers. 7, 85-104.

Goeden, R. D. (1990a). Life history of Eutreta simplex Thomas on ludoviciana Nuttall in southern California (Diptera: Tephrit idae). Pan-Pac. Entomol. 66, 33-38.

Goeden, R. D. (1990b). Life history of Eutreta diana (Osten Sacken) on Artemisia tridentata Nuttall in southern California (Diptera: Tephritidae). Pan-Pac. Entomol. 66, 24-32.

Goeden, R. D. (2002a). Life history and description of immature stages of Oxyna aterrima (Doane) (Diptera: Tephritidae) on Artemisia tridentata Nuttall (Asteraceae) in southern California. Proc. Entomol. Soc. Wash. 104, 510-526.

Goeden, R. D. (2002b). Life history and description of immature stages of Oxyna palpalis (Coquillett) (Diptera: Tephritidae) on Artemisia tridentata Nuttall (Asteraceae) in southern California. Proc. Entomol. Soc. Wash. 104, 537-553.

Goeden, R. D., and Headrick, D. H. (1990). Notes on the biology and immature stages of Stenopa affinis Quisenberry (Diptera: Tephritidae). Proc. Entomol. Soc. Wash. 92, 641-648.

Goeden, R. D., and Headrick, D. H. (1991). Notes on biology, hosts, and immature stages of Tomoplagic cressoni Aczél (Diptera: Tephritidae) in southern California. Proc. Entomol. Soc. Wash. 93, 549-558.

Goeden, R. D., Headrick, D. H., and Teerink, J. A. (1995a). Life history and description of immature stages of Valentibulla californica (Coquillett) (Diptera: Tephritidae) on Chrysothamnus nauseosus (Pallas) Britton in southern California. Proc. Entomol. Soc. Wash. 97, 548-560.

Goeden, R. D., Headrick, D. H., and Teerink, J. A. (1995b). Life history and description of immature stages of Urophora timberlakei Blanc and Foote (Diptera: Tephritidae) on native Asteraceae in southern California. Proc. Entomol. Soc. Wash. 97, 779-790.

Goeden, R. D., and Norrbom, A. L. (2001). Life history and description of adults and immature stages of Procecidochares blanci, n. sp. (Diptera: Tephritidae), on Isocoma ardenia (E. Greene) E. Greene in southern California. Proc. Entomol. Soc. Wash. 103, 517-540.

Goeden, R. D., and Teerink, J. A. (1996a). Life histories and descriptions of adults and immature stages of two cryptic species, Aciurina ferruginea (Doane) and A. michaeli, new species (Diptera: Tephritidae), on Chrysothamnus viscidiflorus (Hooker) Nuttall in southern California. Proc. Entomol. Soc. Wash. 98, 415-438.

Goeden, R. D., and Teerink, J. A. (1996b). Life history and descriptions of adults and immature stages of Aciurina idahoensis Steyskal (Diptera: Tephritidae) on Chrysothamnus viscidiflorus (Hooker) Nuttall in southern California. Proc. Entomol. Soc. Wash. 98, 681-694.

Goeden, R. D., and Teerink, J. A. (1996c). Life history and descriptions of adults and immature stages of Aciurina semilucida (Bates) (Diptera: Tephritidae) on Chrysothamnus viscidiflorus (Hooker) Nuttall in southern California. Proc. Entomol. Soc. Wash. 98, 752-766.

Goeden, R. D., and Teerink, J. A. (1997). Life history and description of immature stages of Procecidochares anthracina (Doane) (Diptera: Tephritidae) on Solidago californica Nuttall in southern California. Proc. Entomol. Soc. Wash. 99, 180-193.

Han, H.-Y., and Kwon, Y. J. (2000). Diptera (Tephritidae). Economic insects of Korea 3. Insecta Koreana Suppl. 10, 1-113. 
Han, H.-Y., and Ro, K.-E. (2016). Molecular phylogeny of the superfamily Tephritoidea (Insecta: Diptera) reanalysed based on expanded taxon sampling and sequence data. J. Zool. Syst. Evol. Res. 54, 276-288. doi: 10.1111/jzs.12139

Han, H.-Y., Ro, K.-E., and McPheron, B. A. (2006). Molecular phylogeny of the subfamily Tephritinae (Diptera: Tephritidae) based on mitochondrial $16 \mathrm{~S}$ rDNA. Mol. Cells 22, 78-88.

Hancock, D. L. (1986). New genera and species of African Tephritinae (Diptera: Tephritidae), with comments on some currently unplaced or misplaced taxa and on classification. Trans. Zimabwe Sci. Assoc. 63, 16-34.

Hancock, D. L. (1990). Notes on the Tephrellini-Aciurini (Diptera: Tephritidae), with a checklist of the Zimbabwe species. Trans. Zimabwe Sci. Assoc. 64, 41-48.

Hancock, D. L. (2001). Systematic notes on the genera of Australian and some nonAustralian Tephritinae (Diptera: Tephritidae). Aust. Entomol. 28, 111-116.

Hancock, D. L. (2003). The status and relationships of Terpnodesma Munro and establishment of the new tribe Axiothaumini (Diptera: Tephritidae: Tephritinae). Afr. Entomol. 11, 143-145.

Hancock, D. L. (2006). Taxonomic updates in some genera and species of Afrotropical Tephritinae (Diptera: Tephritidae). Afr. Entomol. 14, 391-394.

Hancock, D. L. (2007). A review of the fruit fly tribe Eutretini (Diptera: Tephritidae: Trypetinae) in the Indo-Australian region. Aust. Entomol. 34:92.

Hancock, D. L. (2010). A review of the fruit fly tribe Tephrellini (Diptera: Tephritidae: Tephritinae) in the Indo-Australian region. Aust. Entomol. $37,1-6$.

Hancock, D. L. (2012). Systematic and distributional notes on some Australasian and African species of Platensina Enderlein and Dicheniotes Munro (Diptera: Tephritidae: Tephritinae), with description of a new species of Dicheniotes from Kenya. Aust. Entomol. 39, 305-320.

Hancock, D. L., Freidberg, A., and Friedman, A.-L.-L. (2021). "Chapter 71: Tephritidae (true fruit flies)," in Manual of Afrotropical Diptera, Vol. 3, eds A. H. Kirk-Spriggs and B. J. Sinclair (Pretoria: SANBI Publishing), 1511-1576.

Hardy, D. E. (1973). The fruit flies (Tephritidae - Diptera) of Thailand and bordering countries. Pacific Insects Monogr. 31, 1-353.

Harris, P., and Shorthouse, J. D. (1996). Effectiveness of gall inducers in weed biological control. Can. Entomol. 128, 1021-1055. doi: 10.4039/Ent1281021-6

Haseler, W. H. (1965). Life-history and behavior of the crofton weed gall fly Procecidochares utitis Stone (Diptera: Trypetidae). J. Entomol. Soc. Queensland 4, 27-32. doi: 10.1111/j.1440-6055.1965.tb00642.x

Headrick, D. H., and Goeden, R. D. (1994). Reproductive behavior of California fruit flies and the classification and evolution of Tephritidae (Diptera) mating systems. Stud. Dipterol. 1, 194-252.

Huettel, M. D., and Bush, G. L. (1972). The genetics of host selection and its bearing on sympatric speciation in Procecidochares (Diptera: Tephritidae). Entomol. Exp. Appl. 15, 465-480. doi: 10.1111/j.1570-7458.1972.tb0 0234.x

Irwin, J. T., Bennett, V. A., and Lee, R. E. (2001). Diapause development in frozen larvae of the goldenrod gall fly, Eurosta solidaginis Fitch (Diptera: Tephritidae). J. Comp. Physiol. 171, 181-188. doi: 10.1007/s003600000154

Kandybina, M. N., Kovalev, O. V., and Richter,. V. A. (1967). Paratephritis transitoria Rohd. (Diptera, Tephritidae) forming galls on the tassel flower (Cacalia) in the Maritime Province of the USSR. Entomol. Obozr. 46, 113-116 (in Russian).

Korneyev, S. V., Smit, J. T., Hulbert, D. L., Norrbom, A. L., Gaimari, S. D., Korneyev, V. A., et al. (2020). Phylogeny of the genus Tephritis Latreille, 1804 (Diptera: Tephritidae). Arthropod Syst. Phylogeny 78, 111-132. doi: 10.26049/ASP78-1-2020-05

Korneyev, V. A. (1988). A new and little known species of tephritid flies of the genus Terellia R.-D. (Diptera, Tephritidae) from Middle Asia and Transcaucasia. Entomologicheskoe Obozrenie, 67, 871-875.

Korneyev, V. A. (1989). A review of palaearctic species of the genus Hendrella (Diptera, Tephritidae). Zool. Z. 68, 87-92 (in Russian).

Korneyev, V. A. (1999a). "Phylogenetic relationships among higher groups of Tephritidae," in: Fruit flies (Diptera: Tephritidae): Phylogeny and Evolution of Behavior, eds. M. Aluja, A. L. Norrbom, A.L (Boca Raton, FL; London; New York, NY; Washington, DC: CRC Press), 73-114.

Korneyev, V. A. (1999b). "Phylogeny of Tephritinae: relationships of the tribes and subtribes," in Fruit flies (Diptera: Tephritidae): Phylogeny and Evolution of Behavior, eds. M. Aluja, A. L. Norrbom, A.L (Boca Raton, FL; London; New York, NY; Washington, DC: CRC Press), 549-580.
Korneyev, V. A. (2002). New and little-known Eurasian Dithrycini (Diptera, Tephritidae). Vestn. Zool. 36, 3-13.

Korneyev, V. A. (2016). Myopites shirakii Munro 1935 (Diptera: Tephritidae). Available online at: https://figshare.com/articles/Myopites_shirakii_Munro_ 1935_/4262438/1 (accessed July 31, 2021).

Korneyev, V. A., and Evstigneev, D. A. (2013). Key to european species of the genus Oxyna Robineau-Desvoidy, 1830 (Diptera: Tephritidae), with new records from Russia. Ukrainska Entomofaunistyka 4, 1-23.

Korneyev, V. A., and Ovchinnikova, O. G. (2004). "Chapter 79: Fam. Tephritidae Fruit Flies," in Keys to Insects of Far East Russia, Vol. 6, Diptera and Fleas. Part 3, ed. A. S. Leley (Vladivostok: Dal'nauka), 456-564 (in Russian).

Korneyev, V. A., and White, I. M. (1992). Fruitflies of the genus Urophora R.-D. (Diptera, Tephritidae) of east palaearctic. II. Review of species of the subgenus Urophora s. str. (Communication 1). Entomologicheskoe Obozrenie 71, 688-699 (in Russian)

Korneyev, V. A., Zwölfer, H., and Seitz, A. (2005). "Phylogenetic relationships, ecology and ecological genetics of cecidogeneous Tephritidae," in Biology, Ecology and Evolution of Gall-Inducing Arthropods, eds. A. Raman, C. W. Schaefer, T. M. Withers (Enfield, NH: Science Publishers), 321-371.

Korytkowski, C. A. (1976). El género Gerrhoceras Hering, y descripción de una nueva especie de hábitos cecidógenos. Rev. Bras. Biol. 36, 411-417.

Lalonde, R. G., and Shorthouse, J. D. (1985). Growth and development of larvae and galls of Urophora cardui (Diptera: Tephritidae) on Cirsium arvense (Compositae). Oecologia 65, 161-165. doi: 10.1007/BF00379213

Marinkovich, L., Brouwers, E. M., Hopkins, D. M., and McKenna, M. C. (1990). "Late Mesozoic and Cenozoic paleogeographic and paleoclimatic history of the Arctic Ocean Basin, based on shallow marine faunas and terrestrial vertebrates," in The Geology of North America, Vol. L, The Arctic Ocean region, eds. A. Grantz, L. Johnson, and J. F. Sweeney (Boulder, CO: Geological Society of North America), 403-426.

Merz, B. (1992). The fruit flies of the Canary Islands (Diptera: Tephritidae). Entomol. Scand. 23, 215-231. doi: 10.1163/187631292X00308

Merz, B. (1994). Insecta Helvetica Fauna 10: Diptera: Tephritidae. Geneva: HGE Press, 198.

Merz, B. (1999). "Phylogeny of the Palearctic and Afrotropical generaof the Tephritis group (Tephritinae: Tephritini)," in Fruit flies (Diptera: Tephritidae): Phylogeny and Evolution of Behavior, eds. M. Aluja, and A. L. Norrbom (Boca Raton, FL, London; New York, NY; Washington, DC: CRC Press), 629-669.

Muniappan, R., Raman, A., and Reddy, G. V. P. (2009). "Ageratina adenophora (Sprengel) King and Robinson (Asteraceae)," in Biological Control of Tropical Weeds Using Arthropods, eds. G. V. P. Muniappan, and A. Raman (Cambridge, UK: Cambridge University Press), 63-73.

Munro, H. K. (1952). A remarkable new gall-forming trypetid (Diptera) from Southern Africa, and its allies. Union S. Afr. Dep. Agric. Entomol. Mem. $2,329-341$

Munro, H. K. (1953). Records of some Trypetidae (Diptera) collected on the Bernard Carp Expedition to Barotseland, 1952 with a new species from Kenya. J. Entomol. Soc. South. Afr. 16, 217-226.

Munro, H. K. (1957). Sphenella and some allied genera (Trypetidae, Diptera). J. Entomol. Soc. South. Afr. 20, 14-57.

Norrbom, A. L. (1992). A revision of the Nearctic genus Gymnocarena Hering (Diptera: Tephritidae). Proc. Entomol. Soc. Wash. 94, 527-555.

Norrbom, A. L. (1993). New species and phylogenetic analysis of Euaresta Loew (Diptera: Tephritidae) with a key to the species from the Americas south of Mexico. Proc. Entomol. Soc. Wash. 95, 195-209.

Norrbom, A. L. (2006). New species and host records for Gymnocarena (Diptera, Tephritidae). Instrum. Biodivers. 7, 217-226.

Norrbom, A. L., Carroll, L. E., Thompson, F. C., White, I. M., and Freidberg, A. (1999). "Systematic database of names," in Fruit Fly Expert Identification System and Systematic Information Database, Vol. 9, Diptera Data Dissemination Disk (CD-ROM), ed F. C. Thompson (Leiden: Backhuis Publ.), 65-251.

Norrbom, A. L., and Prado, P. I. (2006). New genera and host plant records of Asteraceae-feeding Tephritidae (Diptera) from Brazil. Zootaxa 1139, 1-17. doi: 10.11646/zootaxa.1139.1.1

Norrbom, A. L., Sutton, B. D., Steck, G. J., and Monzón, J. (2010). New genera, species and host plant records of Nearctic and Neotropical Tephritidae (Diptera). Zootaxa 2398, 1-65. doi: 10.11646/zootaxa.2398.1.1 
Norrbom, A. L., Sutton, B. D., Steck, G. J., Nolazco-Alvarado, N., Yabar-Landa, E., Puma, B. L., et al. (2013). New host plant and distribution records for Peruvian Tephritinae (Diptera: Tephritidae). Rev. Peruana Entomol. 48, 19-28.

Novak, J. A., and Foote, B. A. (1975). Biology and immature stages of fruit flies: the genus Stenopa (Diptera, Tephritidae). J. Kans. Entomol. Soc. 48, 42-52.

Novak, J. A., and Foote, B. A. (1980). Biology and immature stages of fruit flies: the genus Eurosta (Diptera: Tephritidae). J. Kans. Entomol. Soc. 53, 205-219.

Prado, P. I., Lewinsohn, T. M., Almeida, A. M., Norrbom, A. L., Buys, B. D., Macedo, A. C., et al. (2002). The fauna of Tephritidae (Diptera) from capitula of Asteraceae in Brazil. Proc. Entomol. Soc. Wash. 104, 1007-1028.

Prado, P. I., Norrbom, A. L., and Lewinsohn, T. M. (2004). New species of Tomoplagia Coquillett (Diptera: Tephritidae) from capitula of Asteraceae in Brazil. Neotrop. Entomol. 33, 189-211. doi: 10.1590/S1519-566X2004000200010

Radhakrishnan, C. (1984). A new Tephrella (Diptera: Tephritidae) from Meghalaya, India. Bull. Zool. Surv. India 5, 41-44.

Romstock, M. (1987). Tephritis conura Loew (Diptera: Tephritidae) und Cirsium heterophyllum (L.) Hill (Cardueae). Struktur- und Funktionsanalyse eines okologischen Kleinsystems. Dissertazion Doctor rerum naturalium Bayreuth, Germany, 142-147.

Sandro, L. H., and Lee, R. E. (2006). Winter biology and freeze tolerance in the goldenrod gall fly. Am. Biol. Teach. 60, 29-35. doi: 10.2307/4451922

Savaris, M., da Luz, F., Lorini, L. M., and Lampert, S. (2019). New distribution record, host plant and notes on natural history of Tomoplagia rudolphi (Lutz and Lima, 1918) (Diptera: Tephritidae). Papéis Avulsos Zool. 59:e20195943:1-8. doi: 10.11606/1807-0205/2019.59.43

Savaris, M., Lampert, S., Lorini, L. M., Pereira, P. R. V. S., and Marinoni, L. (2015). Interaction between Tephritidae (Insecta, Diptera) and plants of the family Asteraceae: new host and distribution records for the state of Rio Grande do Sul, Brazil, Revista Brasileira de Entomologia 59, 14-20. doi: 10.1016/j.rbe.2014.11.002

Schwitzgebel, R. B., and Wilbur, D. A. (1943). Diptera associated with ironweed, Vernonia interior Small in Kansas. J. Kans. Entomol. Soc. 16, 41-43.

Silva, I. M., Andrade, G. I., Fernandes, G. W., and Lemos-Filho, J. P. (1996). Parasitic relationships between a gall-forming Insect Tomoplagia rudolphi (Diptera: Tephritidae) and its host plant (Vernonia polyanthes, Asteraceae). Ann. Bot. 78, 45-48. doi: 10.1006/anbo. 1996.0093

Smit, J., Reijnen, B., and Stokvis, F. (2013). Half of the European fruit fly species barcoded (Diptera, Tephritidae); a feasibility test for molecular identification. Zookeys 365, 279-305. doi: 10.3897/zookeys.365.5819

Stoltzfus, W. B. (1974). Biology and larval description of Procecidocharoides penelope (Osten Sacken) (Diptera: Tephritidae). J. Washington Acad. Sci. $64,12-14$.

Stoltzfus, W. B. (1977). The taxonomy and biology of Eutreta (Diptera: Tephritidae). Iowa State J. Res. 51, 369-438.

Stoltzfus, W. B. (1989). A non-gall forming Eurosta solidaginis (Diptera: Tephritidae). J. Iowa Acad. Sci. 96, 50-51.

Sutton, B. D., Steck, G. J., and Norrbom, A. L. (2012). New species of Gymnocarena (Diptera: Tephritidae) from eastern North America and Guatemala, and the redescription of G. mississippiensis. Can. Entomol. 144, 248-265. doi: 10.4039/tce.2012.25

Tauber, M. J., and Tauber, C. A. (1967). Reproductive behavior and biology of the gall-former Aciurina ferruginea (Doane) (Diptera: Tephritidae). Can. J. Zool. 45, 907-913. doi: 10.1139/z67-102

Tiffney, B. H., and Manchester, S. R. (2001). The use of geological and paleontological evidence in evaluating plant phylogeographic hypotheses in the northern hemisphere Tertiary. Int. J. Plant Sci. 162, S3-S17. doi: $10.1086 / 323880$
Uhler, L. D. (1951). Biology and ecology of the goldenrod gall fly, Eurosta solidaginis. Cornell Univ. Agric. Exp. Station Memoir 300, 3-51.

Varley, G. C. (1937). The life history of some trypetid flies with descriptions of the early stages (Diptera). Proc. R. Soc. Lond. A Gen. Entomol. 12, 109-122. doi: 10.1111/j.1365-3032.1937.tb00967.x

Varley, G. C. (1947). The natural control of population balance in the knapweed gall-fly (Urophora jaceana). J. Anim. Ecol. 16, 139-187. doi: 10.2307/1493

Wangberg, J. K. (1978). Biology of gall formers of the genus Valentibulla (Diptera: Tephritidae) on rabbitbrush in Idaho. J. Kans. Entomol. Soc. 51, 472-483.

Wangberg, J. K. (1980). Biology and immature stages of fruit flies: the genus Eurosta (Diptera:Tephritidae). J. Kans. Entomol. Soc. 53, 205-219.

Wangberg, J. K. (1981). Gall-inducing habits of Aciurina species (Diptera: Tephritidae) on rabbitbrush (Compositae: Chrysothamnus spp.) in Idaho. J. Kans. Entomol. Soc. 54, 711-732.

Warton, R., and Norrbom, A. L. (2013). New species and host records of New World, mostly Neotropical, opiine Braconidae (Hymenoptera) reared from infesting, stem-galling, and stem-mining Tephritidae (Diptera). Zookeys 349, 11-72. doi: 10.3897/zookeys.349.5914

Wasbauer, M. S. (1972). An annotated host catalog of the fruit flies of America north of Mexico (Diptera: Tephritidae). Occas. Pap. Calif. Dep. Agric. Bureau Entomol. 19, 1-172.

Webb, S. D. (1977). A history of savanna vertebrates in the New World. Part I. North America. Annu. Rev. Ecol. Syst. 8, 355-380. doi: 10.1146/annurev.es.08.110177.002035

Zherikhin, V. V. (1994). "Genesis of the Grassy Biomes," in Ecosystem Rearrangements and Evolution of Biosphere. I, eds. A. Rozanov, A. Yu., and M. A. Semikhatov (Moscow: Nedra), 132-137 (in Russian).

Zoogeography of Asian Paleogene (1984). Moscow: Nauka, 302 (in Russian).

Zwölfer, H. (1985). "Insects and thistle heads: resource utilization and guild structure," in Proceedings of the VI International Symposium on Biological Control of Weeds (Vancouver, BC), 407-416.

Zwölfer, H., and Arnold-Rinehart, J. (1993). The evolution of interactions and diversity in plant-insect systems: the Urophora-Eurytoma food web in galls of Palearctic Cardueae. Ecol. Stud. 99, 211-233. doi: 10.1007/978-3-642-58001-7_10

Zwölfer, H., and Romstöck-Völkl, M. (1991). "Biotypes and the evolution of niches in phytophagous insects on Cardueae hosts," in Plant-Animal Interactions: Evolutionary Ecology in Tropical and Temperate Regions, eds. P. W. Price, T. M. Lewinsohn, G. W. Fernandez, W. W. Benson (New York, NY: John Wiley and Sons), 487-507.

Conflict of Interest: The author declares that the research was conducted in the absence of any commercial or financial relationships that could be construed as a potential conflict of interest.

Publisher's Note: All claims expressed in this article are solely those of the authors and do not necessarily represent those of their affiliated organizations, or those of the publisher, the editors and the reviewers. Any product that may be evaluated in this article, or claim that may be made by its manufacturer, is not guaranteed or endorsed by the publisher.

Copyright (๑) 2021 Korneyev. This is an open-access article distributed under the terms of the Creative Commons Attribution License (CC BY). The use, distribution or reproduction in other forums is permitted, provided the original author(s) and the copyright owner(s) are credited and that the original publication in this journal is cited, in accordance with accepted academic practice. No use, distribution or reproduction is permitted which does not comply with these terms. 